\title{
The Role of Financial Slack, Employee Creative Self-Efficacy and Learning Orientation in Innovation and Organizational Performance
}

\author{
Khoa T. Tran ${ }^{1, *}$, Phuong V. Nguyen ${ }^{1}$ and Linh M. Nguyen ${ }^{2}$ \\ 1 Center for Higher Training and Research in Public Administration, International University-Vietnam \\ National University, Ho Chi Minh City 700000, Vietnam; nvphuong@hcmiu.edu.vn \\ 2 School of Business, International University-Vietnam National University, Ho Chi Minh City 700000, \\ Vietnam; ng.mylinh123@gmail.com \\ * Correspondence: ttkhoa@hcmiu.edu.vn; Tel.: +84-28-372-44270
}

Received: 22 October 2018; Accepted: 11 December 2018; Published: 18 December 2018

\begin{abstract}
Organizational performance development and financial slack have drawn extensive attention in management research. Recent studies have indicated that financial slack has a positive effect on innovation outcomes and organizational performance. However, some other studies have proposed adverse effects. This paper aimed to explore the causal linkages between employee creative self-efficacy, learning orientation, financial slack, innovation outcomes and organizational performance. It also examined the influence of innovation performance and creative self-efficacy as mediating variables in the connection between learning orientation and organizational performance. By doing so, we used a structural equation modelling (SEM) method to test the model using data from 267 small medium enterprises (SMEs) in Vietnam. The findings illustrated that SMEs had not utilized financial slack to invest in innovation activities and improve firm performance. Furthermore, the results indicated that learning orientation had both direct and indirect impacts on innovation and firm performance. It is worth noting that employee creative self-efficacy had a positive effect on innovation performance. The findings also verified a statistically significant association between innovation and organizational performance. Finally, the results provided some managerial implications to stimulate employees to work creatively and improve innovation outcomes for sustainable development.
\end{abstract}

Keywords: creative self-efficacy; learning orientation; financial slack; innovation outcomes; organizational performance

\section{Introduction}

Since the implementation of economic reform in 1986, the Vietnamese government has developed a potential local market and economic infrastructure that maintains strong economic growth. Many scholars assert that the development of SMEs has been recognized as one of the most promising growth areas as well as an engine of economic growth, not only in developed countries but also in developing countries (McMillan and Woodruff 2002). Transition economies have accelerated as more and more support for smaller businesses has arisen (Leamer 2007). In Vietnam, SMEs are identified by the government as having a registered capital of $\$ 326,000$ (or less than $\$ 5$ billion) and less than 200 employees. SMEs in Vietnam plays an essential role in the industrialization process of the country. Economic reforms in the past decade have directly stimulated the performance of Vietnamese SMEs and promoted diversification and improved trade and business opportunities. According to the information from the Ministry of Justice, Vietnam in the past few years practised a strong growth of SMEs getting $97 \%$ of the total number of businesses in the nation. 
In the context of sustainable development, SMEs play an essential role in providing economic stability and social security in many regions (Morsing and Perrini 2009). The empirical results demonstrate that SMEs support economies through a considerable source of entrepreneurial skills, innovation and human resources (Hillary 2004; Revell et al. 2010). At the same time, because of the cumulative effect of SMEs, a series of serious environmental problems have been raised. Previous studies have shown that most SMEs are supposed to have no relation to ecological and social issues since indicating that their impact is negligible (Bradford and Fraser 2008; Drake et al. 2004; Revell and Blackburn 2007). To integrate not only in Asia but also in the global region, SMEs in Vietnam need to focus on sustainable development. In the current context, Vietnamese SMEs must overcome many challenges and gain opportunities in global competition. However, the sustainable development of small and medium enterprises is limited in many respects, primarily due to the rapidly changing market and limited internal resources. Restrictions on internal resources include lack of capital, outdated equipment, outdated technology, lack of skills and management experience (Webster and Taussig 1999). Besides, they have faced significant barriers to government regulation. Removing these barriers is a difficult task.

Existing literature proposed that the slack "such as excess liquidity and can, therefore, be easily retrieved if needed for alternative use; in contrast, recoverable slack is slack that is absorbed in operations, such as overhead expenditures and therefore managers have less discretion to use this quickly when necessary" (Wiersma 2017). In other words, slack is a resource to facilitate the implementation of strategies related to the external environment. Previous scholars argued that companies should have enough resources to adequate executive planning and to address unanticipated threats and opportunities. For instance, a study by Pitelis (2007) argues that slack resources play an essential role in explaining an organization's strategy. Similarly, arguing that the more slack resources a company possesses, the more strategic plans the company pursue (Lin et al. 2009). A study of public hospital services in the UK, Salge (2012) found that the level of temporary existence in the organization's creative search activities was determined not only by the difference in terms of structure, ownership and industry membership but also by strategic differences related to strategic aspirations and available resources. In that sense, organizational slacks are considered by scholars as representing the available resources that can be redeployed to achieve business goals (Daniel et al. 2004). Moreover, in an empirical study, Halme and Korpela (2014) demonstrated that SMEs could generate responsible innovations with very distinctive resource combinations.

Bourgeois III (1981) came up with a summary of the definitions in the preceding documents and concluded that "Organizational slack is the cushion of actual or potential resources that allows an organization to adapt itself to internal pressures for change as well as to initiate changes in the strategy for the external environment." Companies may be ready to start and make strategic changes to adapt to the external environment thanks to the slack. There are four types of slack resources: financial slack, slack activity, customer relationship slack and human resource slack (Voss et al. 2008). In which, financial slack is considered as a surplus of financial resources without commitments that can be employed for the organization's strategic activities (Ang and Straub 1998).

Although it is widely known that financial slack affects organizational performance (Bradley et al. 2011), most of the current research has focused on developed markets and has been less focused on emerging economies (Tan and Peng 2003). Some previous studies have suggested that slack resources could allow organizations to continue to innovate, facilitate the development of innovative strategies and create values (Cheng and Kesner 1997; Nohria and Gulati 1996). On the one hand, some studies have suggested that businesses cannot exploit slack on their own; hence, the development of competitive advantage as well as creating innovative value for the enterprise cannot be achieved from these resources (Sirmon et al. 2007; Vanacker et al. 2013). On the other hand, previous scholars have concentrated primarily on investigating the drivers of sustainability expenditure in the developed economies, ignoring potential changes in sustainable financial slack in emerging markets (Zinn and 
Flood 2009). Therefore, in the innovation process, specific differences exist between financial resources slack and large companies and SMEs.

Prior studies indicated the ambiguous relationship between slack resources and organizational performance as empirical research in this field is not conclusive (Geoffrey Love and Nohria 2005; Daniel et al. 2004). Previous management and health studies examined the relationship between the financial resources of the organization and the resulting inconsistent conclusions (Goldstein and Iossifova 2012). Therefore, there is a contradictory view of the relationship between slack resources and organizational performance in management literature. For example, organizational theorists (Cyert and March 1963; Tan and Peng 2003; Daniel et al. 2004) predicted a positive relationship between the two. They proposed that slack resources enhance the company's long-term performance by providing resources for innovation and change and by allowing organizations to absorb the changing environment around them.

Similarly, in a meta-analysis of slack resources studies, the scholars argue that all types of slack resources are beneficial to the organization' s performance and not a source of inefficiency (Daniel et al. 2004). In their recent extensive study of all public non-specialist hospitals in England, Salge and Vera (2013) found that the availability of adequate slack resources positively contributes to building and exercising incremental learning capabilities, which in turn enhance organizational performance in a statistically significant way. In contrast, according to agency theorists (Leibenstein 1969; Majumdar 1998; Basu et al. 2007; Cyert and March 1963), slack is a source of inefficiency because it impedes managers from pursuing risk-taking investments and innovation and instead encourages them to seek opportunities to engage in unjustified diversifications and empire building. Other researchers (George 2005; Tan and Peng 2003) argue for a curvilinear relationship between slack resources and performance.

A learning orientation is defined as the activity of the whole organization to create and apply knowledge for strengthening the competitive advantages (Calantone et al. 2002). Previous arguments that continuous learning will provide plentiful opportunities for employees to explore a variety of perspectives and point of views as well as strengthening a knowledge base to intensify problem-solving skills and innovation process (Amabile 1988; Ericsson et al. 1993; Ford 1996; Gist and Mitchell 1992). This research concentrated on exploring the different findings in previous studies by investigating the mechanism of influences between learning orientation and creative self-efficacy. It may be necessary for reconciliation to develop and produce an effect recommended by (Shin and Zhou 2003). However, prior research did not study the psychological mechanisms that brought about creativity, except (Shin and Zhou 2003). They found internal motivation (e.g., interest and enjoyment): creative self-efficacy-the belief that people have the knowledge and skills to produce creative results (Tierney and Farmer 2002). Self-efficacy is based on one's knowledge and skills that allow creativity. Because effective belief fosters intrinsic motivation by increasing awareness of self-control (Bandura 1986; Deci and Ryan 1985), creative self-efficacy may also reflect intrinsic motivation to participate in creative activities.

This paper aimed to gain more insight into the causal linkages between financial slack, learning orientation, innovation outcomes and organizational performance. Our study attempted to seek answers for such problems by using empirical data to test the direct and indirect influence of innovation performance and creative self-efficacy as mediating variables on the connection between learning orientation and organizational performance. Moreover, this study also examined the effect of financial slack on innovation outcomes and organizational performance as previous studies have hardly investigated these relationships. In investing these contingencies, this paper highlights scholarly knowledge by illustrating how certain scenarios in emerging markets and characteristic circumstances of SMEs assist widen the understanding of the determinants of innovation and organizational performance. Finally, we provide some managerial implications and the conclusions of this study.

The following section describes the literature review. The method of research is presented in Section 3. Meanwhile, the research results were explained in Section 4. Discussions and implications 
are presented in Section 5. Meanwhile, Section 6 reports our conclusions. The final section provides some limitations and suggests for further study.

\section{Literature Review}

\subsection{Learning Orientation}

Learning orientation is defined as the activity of the whole organization to create and apply knowledge for strengthening the competitive advantages (Calantone et al. 2002). These activities are described as a process of information gathering, information dissemination, as well as the interpretation to increases the effectiveness of both individuals and organizations (Hurley and Hult 1998; Moorman and Miner 1998; Mone et al. 1998). It also influences the decision on which information to collect (Dixon 1992) and how it is interpreted and evaluated (Argyris and Schon 1996; Sinkula et al. 1997). Prior scholars indicate that learning orientation play a critical role in the enhancing the effectiveness of identifying customer needs, market changes and competitor actions, as well as the development of new technologies to create new products that are superior to those of competitors (Mone et al. 1998; Moorman and Miner 1998; Hurley and Hult 1998). It also refers to the extent of a company's ability to promote generative learning as a core competency (Sinkula et al. 1997). Learning orientation is composed of four dimensions: (1) commitment to learning, (2) shared vision, (3) open-mindedness and (4) intra-organizational knowledge-sharing (Calantone et al. 2002; Hurley and Hult 1998; Hult and Ferrell 1997; Sinkula et al. 1997). Those are the key dimensions we focus on investigating in this study.

\subsubsection{Commitment to Learning}

A commitment to learning refers to the level of respect and encouragement of learning, as well as the ability to promote the learning climate of an organization (Sinkula et al. 1997). According to Calantone et al. (2002), organizations with high levels of learning commitment would consider learning as a vital investment for survival, the short-term investments that bring long-term gains and effect to long-term strategic direction. For instance, managers in those organizations expect that employees use company time to pursue knowledge beyond their scope of work. If an organization does not encourage the development of knowledge, employees will have no incentive to pursue learning activities (Slater and Narver 1994).

\subsubsection{Shared Vision}

A shared vision is conceptualized as the concentration of the whole organization into learning. Without a shared vision, the learning of an organization becomes meaningless (Sinkula et al. 1997). In that sense, this refers to the common problem when employees are willing to learn but do not know what to learn. Besides, the lack of a shared vision also leads to the fact that creative ideas will not be implemented for the diverse interests of the organization (Hult 1998). Therefore, to create an active learning climate, organizations need a clear and shared vision on a consistent basis and the entire. Brown and Eisenhardt (1995) have shown that the reception of information and perceptions from different functional areas in an organization varies. Therefore, this will create a diversity in the way employees perceive and handle data in different functional departments. Based on learning theory, shared vision is formed through internal communication when cross-functional communication barriers are removed to increase information flow and coordinate action tightly between different departments within the same organization (Brown and Eisenhardt 1995).

\subsubsection{Open-Mindedness}

According to (Sinkula et al. 1997), open-mindedness is considered to be essential in daily activities and accepting new ideas of an organization. In that sense, it is considered as a process when the organization seriously evaluates their current knowledge as well as old assumptions, habits (Nguyen and Barrett 2006), transform into new habits (Sinkula et al. 1997). Today, businesses have to 
face rapid changes from the market, while new technologies are continually being born. The issues of knowledge obsolescence occur in most sectors. If the organization has the open-mindedness to question them and continue to learn lessons in the past, which may still be instructive (Verona 1999; Porac and Thomas 1990; Sinkula 1994). Continuous updating and refreshing of the knowledge base are needed as drawing lessons from past mistakes.

\subsubsection{Intra-Organizational Knowledge Sharing}

Intra-organizational knowledge-sharing is a collective belief or behavioural practice that involves the diffusion of learning between different units within an organization (Moorman and Miner 1998). It maintains knowledge and information collected from various sources and serves as a reference point for future actions (Calantone et al. 2002). Without the accumulation of knowledge, the learning process would be limited even if an organization is committed to learning and has a shared vision (Moorman and Miner 1998). For example, the marketing department's experience with customers can be valuable to $\mathrm{R} \& \mathrm{D}$ units in developing products or services. Intra-organizational knowledge-sharing is also about getting information from a variety of sources, which requires the involvement of the organization in the reprocessing of the system and the structure of the information. It is essential that all functional departments in an organization share experiences and knowledge with each other, which should also be stored in organizational memory. In order to prevent the loss of information, intra-organizational knowledge sharing is necessary due to employee turnover and transfer (Lukas et al. 1996), even though the accumulation of individual learning leads to learning in an organization.

\subsection{Self-Efficacy \& Creative Self-Efficacy}

Self-efficacy is asserted as the primary influence of how people feel, think, motivate themselves and behave in the study of (Bandura 1992). This paper also indicated that the recognition of self-efficacy not only has a direct impact on the choice of actions but also reflected in the expectations of ultimate success. Prior studies have identified self-efficacy as an essential factor affecting individual performance and attitudes at work (Avey et al. 2010; Culbertson et al. 2010). The expectation on self-efficacy also determines the extent of effort people will spend and how long they will remain in the face of difficulties and challenges: the more effective confidence, the more positive the effort. Self-efficacy constitutes a powerful influence on cognitive processes revealed in a study and decision-making (Bandura and Wood 1989). These multiple effects of self-efficacy are formed through four important processes: cognitive, motivational, emotional and selection processes (Bandura 1992). The stronger the perceived self-efficacy, the higher the challenge people set for themselves and the firmer commitment (Bandura 1991).

In the social cognitive theory, Bandura (1977) first proposed that self-efficacy play a motivating role in the process of creation and innovation. He states that strong self-efficacy is necessary for creative productivity. His point of view about self-efficacy is its influence on motivation and ability to involve in specific work as well as the pursuit of particular tasks. The concept of self-efficacy is necessary for understanding creative ability in organizational settings. Bandura (2001) argues that the structure of self-creation derived from the social cognitive theory. However, it was the more general construct of self-efficacy that played a central role. Tierney and Farmer (2002) pointed to the lack in the management literature about creative self-efficacy, which is capable of predicting original performance, until the beginning of the twenty-first century.

Other theoretical propositions in creative research either explicitly included in their model a construct related to efficacious beliefs (Ford 1996). Moreover, Hennessey (2003) refers to it as a possible outcome of differences in intrinsic motivation. Ford (1996) also developed a theoretical model of creativity in organizational settings in which self-efficacy plays an important role. The basis for the development of a self-efficacy is constructed in the model in organizational settings (Gist and Mitchell 1992) and the theory of individual creative action (Ford 1996). He also proposed 
self-efficacy belief as the key motivational component in his model of individual creative action. In that sense, Luthans et al. (2007) conceptualized creative self-efficacy as one's confidence to perform a specific task in the innovation process. Employees with higher levels of creative self-efficacy tend to produce more creative outcomes (Tierney and Farmer 2002). Furthermore, these scholars considered creative self-efficacy as "the belief one has the ability to produce creative outcomes."

\subsection{Financial Slack}

Previous research (Ang and Straub 1998) has conceptualized financial slack as excessive financial resources; which is not a necessary expenditure to maintain the organization's operations; therefore, it is possible to use them as discretionary funds (Dimick and Murray 1978). Financial slack represents the potential for money they can raise from outside, such as banks and the government, which does not only mean excess liquidity of firms (Wang and Cheung 2004).

Financial slack is mentioned in various forms in literature. For instance, Bourgeois III and Singh (1983) divide the slack resource into three types: (ready) available slack, recovery (with some effort) slack and potential slack. This division is based on the ease or speed of resources recovery. Besides, it can distinguish between deliberately created delays by management and environmental degradation (Bourgeois III 1981). On the other hand, Singh (1986) divides the slack into slack absorption and does not accept slack, in which the former referred to slack absorption as cost and later refers to liquid resources are not committed.

Our study focused on two forms of three types of slack introduced by (Bourgeois III and Singh 1983): (1) available slack and (2) potential slack. Available slack refers to additional resources that have not yet explicitly committed, which will allow managers to use resources most flexible. Cash and market securities represent available resources. Most empirical studies of slack and performance use current scaling as a proxy for slack availability (Daniel et al. 2004). The current ratio refers to a liquidity ratio that measures the solvency of a company's short-term liabilities and is calculated as the current asset divided by the current liabilities. Potential slack refers to the resources that can be created in the future by changing economic environments; for example, the potential for raising capital such as stock price fluctuations. Numerous empirical studies use leverage as the ratio of debt to equity to measure shortfall (Daniel et al. 2004).

Moreover, Bourgeois III (1981) came up that if the debt-to-equity ratio decreases, "future interest payment to obligations are reduced, as is the potential for outsiders (creditors) to affect managerial policy." The increase in the debt-to-equity ratio shows the potential decline. In the same context, two types of slack—available slack and potential slack-correspond to a proposal by (Sharfman et al. 1988) "high discretion slack" and "low discretion slack."

Since financial slack is more flexible than other slack resources as businesses can easily take it into various activities or new projects (George 2005). Besides, it is easier to convert the financial slack into another kind of slacks (Dollinger 2008). Therefore, this study concentrated on investigating the financial slack with measurement scale adapted from prior studies (Boso et al. 2017; Zhang et al. 2018).

\subsection{Innovation Performance}

Previous scholars suggested that innovation performance could be achieved through a series of innovative activities (Alegre and Chiva 2013; Verhees and Meulenberg 2004). Based on this idea, Wang and Ahmed (2004) have proposed that innovation performance includes "introduce-[ing] new products to the market." According to Sethi et al. (2001), this view establishes a broad view of innovation performance, which is lacking in previous studies. Existing literature has suggested the importance of promoting innovation (Johannessen et al. 1999; Ozer 2004; Ritter and Gemünden 2003), especially for small businesses and the new venture (Corso et al. 2001; Rothaermel and Deeds 2006; Walter et al. 2006; Johannessen et al. 1999).

Over the past few years, many Vietnamese enterprises have been continuously developing and investing in technological innovation, step by step possessing imported technologies, from which they have created good quality products, raising high competitiveness in domestic and international markets. However, the pace of technological innovation in most businesses is still slow. For example, 
the penetration rate of advanced technology in other countries in Southeast Asia is as high as 30\% in Thailand, $51 \%$ in Malaysia, $73 \%$ in Singapore and Vietnam only is $2 \%$, slow. Besides, investment and development of technology innovation of Vietnamese enterprises have not been much improved. Almost $97 \%$ of Vietnamese enterprises are small and medium enterprises (SMEs). They still use outdated technology that may have lagged three-four generations in the world. Most companies have used technology in the 1980s and the ability to innovate in research and technology is limited. The advanced technology approach of enterprises is minimal (Lang et al. 2012).

Moreover, the level of human resources in scientific innovation and technology management is still limited to the current level of expertise in Vietnam (Vu and Hoang 2010). Therefore, the ability to innovate technology in Vietnam has not been fully exploited to improve the competitiveness of the company as well as promote the economy. Hence, in order to verify the level of innovation and performance of enterprises, we conducted the research based on the data collected in the context of SMEs in Vietnam.

\subsection{Organizational Performance}

Delaney and Huselid (1996) stated that the perceived organizational performance measure faces with essential issues such as "product quality, customer satisfaction and new product development." Therefore, examination of alternative dependent variables and samples should provide distinctive confirmatory information on the association with antecedents. Also, measuring organizational performance is viewed as an increasingly challenging activity (Parnell et al. 2012), especially when researchers apply Western scales to non-Western countries (Jusoh and Parnell 2008).

There are many different ways to measure organizational performance and there is no such comprehensive measure. Each method provides only a partial, misleading view of organizational performance; further, the functions and activities of different parts of the organization are incredibly diverse. However, Elbanna (2012) and Fadol et al. (2015) have extended prior studies by combining three perspectives on performance (private business, learning and growth and client perspectives), balancing different aspects of organizational performance and thus describing it in its entirety. This approach is more likely to be appropriate to assess perceived organizational performance.

\subsection{Learning Orientation and Innovation Performance}

Learning orientation is closely related to organizational innovation. Previous scholars have asserted the critical role of learning orientation to conducting innovation capability (Cahill 1996). A learning orientation has been defined as an individual's dedication to developing their competence (Dweck and Leggett 1988; Dweck 2000). Through organizational interaction as well as observations of the working environment, the implementation of learning occurs. Some crucial environmental factors should be noted as market demand uncertainty, technological turbulence and competitive uncertainty during the innovation process (Cahill 1996). Thus, learning-oriented organizations can conduct their innovation capability for these following reasons. First, learning-oriented organizations are more likely to be committed to innovation, because of the ownership of modern technology and the implementation of technology initiatives.

Second, these organizations, which can clarify customer needs, could take part in the opportunities in the emerging market given its ample and uncertainty demand (Cahill 1996; Damanpour 1991). According to Urban and Hauser (1980), the ability to understand their customer needs is essential for a firm. He uses the term "core benefit proposition," which emphasizes that organizations must gain a full understanding of the expressed and latent customer needs through their interactions and observations with customers. These needs must be clear and concise and connect directly to product strategy. In order to gain a better understanding of market demand in the current uncertain, businesses need to equip themselves with a solid knowledge base and continuously innovate as well as enhance their ability to their improve products continuously. 
Third, according to Damanpour (1991), a learning-oriented organization tends to have greater innovation capability than its competitors. Furthermore, those organizations can closely monitor their competitors' actions in the market (Gatignon and Xuereb 1997). This leads to a good understanding of their rivals' strengths and weaknesses and uses all the opportunities for learning from not only their successes but also their failures (Lant and Montgomery 1987; Slater and Narver 1994).

Besides, in a transitional market, such as Vietnam (where business values are included in a centralized planning system), learning-oriented firms can withdraw from the business and apply new market interpretations; This involves a market-oriented approach. Market-oriented behaviours and learning support the learning process of the organization and continuously encourage the creation, sharing and use of new and more profound knowledge (Baker and Sinkula 1999; Slater and Narver 1994). Learning orientations can help to promote firm market-oriented thinking and behaviour (Jaworski and Kohli 1996). An excellent learning environment promotes the use of all resources, including behaviour that accompanies market orientation (Baker and Sinkula 1999). Learning-oriented organizations are likely to be involved in adaptive and generative learning (Hult 1998; Argyris and Schon 1996).

All of these findings contribute to a high innovation capability. Hence, we propose the first hypothesis:

Hypothesis 1 (H1). Employee learning orientation is positively related to innovation performance.

\subsection{Learning Orientation and Creative Self-Efficacy}

Weisberg (1999) found learning to be essential for creativity. Since working knowledge is stable, personal factors shape self-efficacy assessment (Gist and Mitchell 1992) and creativity performance (Amabile 1983). There are two sources of knowledge acquisition: formal education and working experience, which represent personal resources to an employee for creative performance. It could be argued that task familiarity would lead to more "habitual" performance (Ford 1996); however, Ericsson et al. (1993) stated that there were also ample opportunities for employees to enhance their creative ability through intentional practising task-domain skills and activities regularly, as well as, educational experiences were essential for creative tendencies and process development. This might lead to the advancement of cognitive function including an orientation toward the use of diverse, multiple perspectives (Perkins 1986). Continuous learning provides ample opportunities for employees to explore a variety of perspectives and point of views as well as strengthening their knowledge base to enhance problem-solving skills and innovation processes.

It leads to the indication that learning orientation seems to support and enhance the formation as well as the maintenance of an individual's creative self-efficacy for several reasons. First, learning orientation is a critical base in elaborating malleable ability and efficacy beliefs (Bandura 1977; Dweck and Leggett 1988; Tierney and Farmer 2002). Second, learning-oriented employees tend to focus on developing competence (Dweck and Leggett 1986; Dweck 2000). In other words, they have the ability to accumulate experience and manage time efficiently. With the consistent accumulation of experience and skills, self-efficacious and creative outcomes gradually improve over time. Finally, as employees focus on improving their self-competence, it characterizes their learning orientation. The attempt to achieve creative outcomes are necessarily challenging and risky (Bandura 1997). Furthermore, instead of focusing on the external, those employees that pay attention to self-improvement are shielded from unexpected adverse reactions that may arise during the creative process. In other words, by consistently improving self-competence, learning-oriented individuals can maintain efficacy beliefs throughout the uncertainty of the creative journey.

\subsection{Creative Self-Efficacy and Innovation Performance}

There is an intrinsic connection between innovation and creativity (Robinson and Beesley 2010), where creativity is the generation of new ideas (Sarros et al. 2008) and innovation emphasizes the implementation of those creative ideas. Therefore, organizations must spread creative activities 
among their employees to develop a solid business framework (Nieves et al. 2014). According to social cognitive theory (Bandura 1997), individual motivation is fostered by personal judgments of self-capabilities to perform particular tasks (or behaviours) and by their expectations of the outcomes. Their autonomy will affect their ability, self-confidence as well as self-efficacy.

High creative self-efficacy oriented employees can generate motivation, be aware of resources and implement needed actions to cope with situational demands. They focus on recognizing problems cognitively as well as brainstorming innovative ideas or solutions. The majority of their effort is seeking the generation of ideas and producing prototypes. Therefore, they are fully capable of accomplishing specific tasks and helping the organization overcome challenges during the innovation process (Baer et al. 2008; Gong et al. 2009; Phelan and Young 2003; Tierney and Farmer 2002). In addition, Camio et al. (2018) contributed elements to the theory of capabilities that a firm with great creative capabilities would achieve a high innovation performance.

In addition, the development of employee creativity comes from interactions with customers. Employees must demonstrate creativity in solving customer problems as well as dealing with unexpected failures or events. Responding to uncertain situations improves an employee's ability to create new ideas or solutions incessantly, which is especially useful for today's innovation (Seligman and Csikszentmihalyi 2000). Furthermore, in a recent study by Riaz et al. (2018), they confirmed the important role of thriving at work in engaging innovative behaviour. To clarify the relationship between creative self-efficacy and innovative performance, this study aimed to examine whether individuals with high creative self-efficacy would exhibit greater innovative performance or not. Hence, Hypothesis 2 is proposed:

Hypothesis 2 (H2). Creative self-efficacy mediates the relationship between employee learning orientation and innovation performance.

\subsection{Learning Orientation and Organizational Performance}

Several previous studies have indicated that knowledge has become the most critical resource for organization performance because it can integrate the other tangible resources effectively, which boosts a company's overall performance as well as enhances its innovative ability (Kogut and Zander 1992; Grant 1996). Previous studies have stressed the importance of learning for company survival and effective performance (Argyris and Schon 1996; Fiol and Lyles 1985; Senge 2006; Inkpen and Crossan 1995). In general, learning orientation has a positive influence on performance improvements. This positive effect often occurs in both technology companies and manufacturing companies (DeCarolis and Deeds 1999; Argyris and Schon 1996; Fiol and Lyles 1985; Senge 2006). Companies show that the breadth, depth and speed of organizational learning have higher levels of efficiency (Hurley and Hult 1998).

As social cognitive theory has suggested, the knowledge acquisition of an individual occurs through directly attaining and experiencing a specific task or skill, thus learning from the actual observation of proficiencies (Bandura 1997). In addition, Eisenhardt and Santos (2002) also indicated that the acquisition of knowledge and skills or organizational learning implicit how new information can be absorbed to boost overall company performance. Although knowledge has often been studied from the perspective of personalization, some studies have shown that it can be used from the organizational level through information management, communication and cooperation with mutual benefits (Eisenhardt and Santos 2002; Kogut and Zander 1992). In the context of the environment of SMEs, (Roy and Thérin 2008) argued that knowledge is the primary source of competitive advantage since knowledge acquisition plays a role as the decisive factor.

Learning orientation involves cognitive and behavioural change. More than ever, organizational learning has become a demand rather than a choice. The inability to learn is the reason most companies disappear before forty years have passed (Argyris and Schon 1996; Senge 2006). The primary purpose of learning is to improve the quality and quantity of performance, allowing the company to increase 
and improve revenue; to achieve more support; and create, maintain and expand its customer base. Besides, learning orientations will rapidly increase strategic capabilities, allowing organizations to maintain a competitive advantage and improve their performance. The attitudes, behaviours and strategies of this learning orientation will guide organizations to achieve high performance in the long run. In an organization to maintain or improve performance based on experience, learning involves the acquisition of knowledge (development or creation of skills, details and relationships), sharing knowledge (disseminated to others) and use of knowledge (learning integration to be assimilated and widely available) and can be generalized to new situations (DiBella et al. 1996, p. 363).

Specifically, regarding the sustainable development perspective of a company, knowledge can help determine their degree of sustainability (Uhlaner et al. 2012; Roy and Thérin 2008). In the context of the environment of SMEs, (Roy and Thérin 2008) argued that knowledge is the primary source of competitive advantage since knowledge acquisition plays a role as the decisive factor for innovation. Aragón-Correa et al. (2008) also proposed that the acquisition of knowledge not only conducts the sustainability performance but also enables the organization to perceive and understand issues regarding sustainable development, which is also considered as a unique competitive advantage. Besides, when it comes to innovation, the performance of sustainable implementation is also understood as the adaption of environmental and social standards and the firm's economic interest coincidently. The primary challenge of sustainable innovation is how the company can balance and control those environmental and social consequences but still, maintain the performance of their business. In other words, company leaders should pay attention to the normative requirement that business models should meet to support sustainable innovations (Boons and Lüdeke-Freund 2013). Therefore, SMEs must be flexible in applying technology as well as continuously gaining knowledge to adapt their strategies for ecological and social challenges. Hence, we propose Hypothesis 3:

Hypothesis 3 (H3). Learning orientation is positively associated with organizational performance.

\subsection{Financial Slack and Organizational Performance}

From a slack resource theory standpoint, the flexibility from abundant financial slack has allowed firms to be capable of affording the investment in sustainability causes (Cheng et al. 2014; Orlitzky et al. 2003). Empirical evidence has demonstrated the positive relationship between greater retained profit and social performance (Waddock and Graves 1997). In that sense, those firms with greater financial slack are expected to have more social and environmental sustainability causes (Brammer and Millington 2004; Adams and Hardwick 1998). However, other cross-national studies have found an adverse effect for such relationship (Surroca et al. 2010). Julian and Ofori-Dankwa (2013) prove from a developing-economy market perspective that aside from the benefits of the flexibility from abundant financial slack, it also causes firms to significantly reduce their investment in social and environmental sustainability causes due to protecting their business interests. Moreover, SMEs located in developing economies, instead of investing more in sustainability causes, they pay more attention to building their core operational activities due to lack of financial slack.

In developing markets, the decisions of SMEs to not invest much in sustainable implementation can be understood for several reasons. First, studies have shown that consumers in developing economies place more priority on economic concerns than on sustainability due to a lack of understanding about sustainable benefits (Sudarmadi et al. 2001). Typically, those consumers are more concerned with the level of income and daily living expenses than sustainable interests (Khavul and Bruton 2013; Loayza et al. 2000; Viswanathan et al. 2012). Another study has further elucidated this finding for consumers in South Africa when referring to environmentally friendly packaging. The results showed that these consumers had a limited understanding of how to use environmentally friendly packaging and how to distinguish them from conventional ones (Scott and Vigar-Ellis 2014). Second, in developing economies, the mobilization of capital from external sources has always faced some difficulties due to the poor development of the stock market as well as 
limiting access to foreign capital. In addition, the financial credibility of SMEs in developing countries is typically underappreciated.

Consequently, when combined with typical consumer behaviour in these economies, it is reasonable for firms to spend a great deal of capital and internal resources to improve their operational activities, instead of investing in sustainable causes (Julian and Ofori-Dankwa 2013). Third, in developing economies, policy-makers often encourage firms to prioritize employment, rather than focusing on social regulation (e.g., labour safety) and the environment (e.g., waste disposal). In policy discussions, such issues are raised to address corruption and weak enforcement (Tang et al. 2012).

Moreover, contrary to the company's behavioural view, many agency theorists consider managers as agents of the company's shareholders and argue that the less financial slack a company has, the better. Managers have incentives to use slack resources solely for the lavish indulgence of management. Institutional Theory of Institutional Research focuses on agent issues between shareholders and managers within the company. The problem of the agency is since shareholders seek to increase their value firmly and managers pursue their own interests at the expense of shareholders. Without proper supervision, managers waste the resources available to pursue their own interests. For example, as financial declines such as free cash flow increase, poor projects may be financed because managers have the incentive to invest slack resources in net present value projects to pursue their own benefits (Jensen 1986). As a result, financial slack can endanger corporate performance. For institutional theory, organizational slack is considered unnecessary. A practical sense of this view is related to the reduction of organizational size to economic efficiency. That is to say, eliminating organizational slack improves organizational performance. This view is in line with Kornai (1979) view of soft budget constraints. Thus, we argue that:

Hypothesis 4 (H4). Financial slack is negatively related to organizational performance.

\subsection{Financial Slack and Innovation Performance}

Existing literature suggests that high-discretion financial slack (cash and receivables available) allow the firm to develop their other capabilities. In other words, it can be diverted or redeployed to develop other internal capabilities (Nohria and Gulati 1996; George 2005) and support for the invention of new product or technology (Mishina et al. 2004). Scholars have shown that financial slack influences management decision-making (Singh 1986), which facilitates the process of new product development (Mishina et al. 2004) and affect risk management. While low financial decisions (debt) provide lower flexibility for managers and their strategic plans, high financial slack (cash and cash equivalents) can be quickly deployed. If a firm has limited financial competence, they need to maintain a satisfactory financial position; therefore, managers tend to favour highly profitable activities. Its availability influences the decision of managers to seek new coalition partners. Moreover, with high-discretion financial slack, ventures can provide implicit strategic flexibility (Romanelli 1987) and facilitate adaptation to complex external conditions (Tan and Peng 2003). In case of sufficient financial slack, the concerns about paying back-time and short-term expenses would be eliminated. Moreover, a company can hire new professionals and buy new equipment or materials that can improve its capabilities (Danneels 2008). Therefore, it is the centre of the development of every company (Dollinger 2008). Implicitly, financial slack plays a role in enabling the organization to flexibly respond to unforeseen events and fluctuations from the external environment.

On the other hand, there are also two other theoretical streams in exploring the role of slack in the privately held firm: the research on the behavioural theory of the firm (March 1994; Cyert and March 1963). The proponents of behavioural theory indicate that firms work as coalitions of actors. In particular, by allowing related parties to pursue their agendas, managers can take advantage of slack opportunities to appease their political coalitions exploring the role of slack in privately held firms: the research on the behavioural theory of the firm (Cyert and March 1963). Prior researchers amplify this notion by arguing that slack facilitates internal control more flexible; simultaneously, 
the creation of funds can be diverted to projects with unpredictable results, fostering the environment for innovation (George 2005). Based on this theoretical line, the evidence shows the positive effect of the financial slack on innovation and efficiency (Bromiley 1991; Damanpour 1987; Greve 2003).

Alternatively, some economic arguments have been used to articulate the influence of slack on firm performance (e.g., Deephouse and Wiseman 2000). In this study, we build our arguments using organizational theories on slack in order to discover more clearly and accurately the relationship between financial slack and innovation performance. In some instances, organization theory suggests slack as facilitating strategic behaviour, which enables a firm to cultivate their ideas in their infancy and moreover introduce new products and enter new markets (Thompson 1967). Furthermore, slack resources play a role as a core element in facilitating the pursuit of untested, novel ideas. In that sense, organizational theory suggests that the availability of excessive resources allows managers to safely experiment with new innovative strategy as well as creative projects without being considered (Cyert and March 1963). Consequently, instead of focusing the majority of efforts on responding to unexpected situations, organizations should focus on expanding innovation as well as pursuing new projects, improving processes, or developing new markets with potentially high payoffs (Simsek et al. 2007; Voss et al. 2008).

In addition, Singh (1986) came up with a psychological perspective of slack that it would promote risky behaviour. Previous studies have indicated that the degree of managers' risk tolerance tends to be higher when there are abundant slack resources and less so when resources are scarce (Audia and Greve 2006; Voss et al. 2008). Slack resources enable the managers' organizations to avoid the threat of failure by increasing their investment in innovative competencies so that they can respond to low performance. In contrast, when scarce resources are limited, the danger to organizational survival is low performance. At that time, top managers need "to reduce investments in innovative ventures and revert to tried and tested competencies with more predictable outcomes that limit potential losses." (Voss et al. 2008). This implies that managers of organizations or small businesses can take advantage of financial slack as a tool for diversifying strategies to respond effectively to chain conditions. Therefore, it leads to the conclusion that with financial slack, firms would perform a higher level of unique capabilities and innovation than their competitors. Thus we suggest:

Hypothesis 5 (H5). Financial slack is positively associated with innovation performance.

\subsection{Innovation Performance and Organizational Performance}

The difference and division between countries, sectors and specific companies is the ability to innovate (Porter 1985). It not only contributes to the long-term and continued revenues but also helps to improve the quality of products and services, to diversify products, to enhance productivity and responsiveness and solvency as well as job satisfaction. Innovation also determines the ability to protect market share and extend to the new ones and furthermore increase customer credibility and help companies reduce unnecessary costs (Abernathy and Clark 1985; Cooke and Mayes 1996). Some non-economic arguments for innovation have focused on better social and environmental sustainability that provides a significant social position (Elkington 1997; Larson 2000). The novelty of change, however, is less relevant than the fact that ideas, practices, or objects are new to the unit of operation (Bhaskaran 2006).

Elkington (1997) contributed to the broader dissemination of the triple P bottom line of sustainable development. Most of the available research on sustainable improvement and performance applies to large companies. However, in practice, the process of innovation for SMEs is different. The sustainability of the company is known by a variety of definitions, which range from contributing to society and the environment to producing the least adverse effects in the production chain. Factors such as competitive advantage, profitability, increased stakeholder pressures, legal requirements, reputation concerns, environmental improvements and internal organization improvements play a considerable 
role in examining the sustainable development of an organization (Daily and Walker 2000; Marcel van and Werre 2002).

According to Lin et al. (2018), innovative behaviour is known as the key resource for maintaining organizational competitive advantage and sustainable development. Blum-Kusterer and Hussain (2001) stated that sustainability was an innovative and transformative force that created new products and business processes that challenged the current ones. In this context, sustainability initiatives are implicated as innovations where the novel improvement of a product, service, process or technology not only results in economic efficiency growth but also promotes social and environmental performance, both in the short and long-term (Biondi et al. 2002; Von Weizsäcker et al. 1998). Moreover, it also brings the integration of stakeholder requirements into decision making and aims to make a new enhancement. Sustainable innovations are fundamentally transformational (Rycroft and Kash 2000).

One of the main strategic priorities of SMEs should concern for developing green product innovation "to achieve growth, environmental sustainability and a better quality of life" (Dangelico and Pujari 2010) The challenge of integrating economic, social and environmental aspects at the same time has provided a different perspective on sustainable innovation, which is entirely different from previous indications. Today's innovation implies not only increasing economic benefits but also making more positive contributions to society and the environment. Thus, we propose:

Hypothesis 6 (H6). Innovation performance has a positive impact on organizational performance.

\section{Methodology}

Provided the likely impacts of the study context, this paper emphasizes the exploratory character. Although the longitudinal study is essential in tracking changes over time, the limits of time and the research funding force us to select a cross-sectional approach. Besides, it is too hard to observe changes in organizational performance and its antecedents over time. It is worth noting that cross-sectional data are blamed as less accurate than longitudinal data due to errors related to memory and biased behaviour (Fadol et al. 2015). We attempted to diminish this impact throughout asking correspondents to answer the questions with respect to their enterprises at the time that they filled out the survey.

\subsection{Measures}

All questionnaires were translated from English into Vietnamese and then translated back into English to ensure equivalency of meaning. Based on the Brislin et al. (1973) back-translation procedure, we asked two lecturers in the English language and linguistics to implement the back-translation to ensure that the English and Vietnamese versions of the items were similar and any discrepancies were solved. All the variables were measured on 7-point Likert-type scales, with 1 representing strongly disagree to 7 representing strongly agree.

All of the measurement items used for this research were adapted from the literature. Moreover, we also conducted two group discussions with ten entrepreneurs of various organizations to identify and develop the Vietnamese questionnaire based on the measures of the English version. This enabled us to create an appropriate questionnaire that was easily read and answered within the Vietnamese context and culture.

Referring to a comprehensive literature review, the paper constructed a 19-item measurement scale to investigate five latent variables mentioned in Figure 1. First, Learning orientation was adapted from (Jyoti and Dev 2015), who adapted prior studies (Hurley and Hult 1998; Sinkula et al. 1997) to construct four dimensions: intra-organizational-knowledge sharing, open-mindedness, shared vision and commitment to learning. However, following recommendations from the group discussions on how to generate short scales, we removed all sub-factors as the participants found it confusing to answer all items. Hence, we used a four-item short scale to capture learning orientation. These adaption items were also applied by (Jyoti and Dev 2015). 


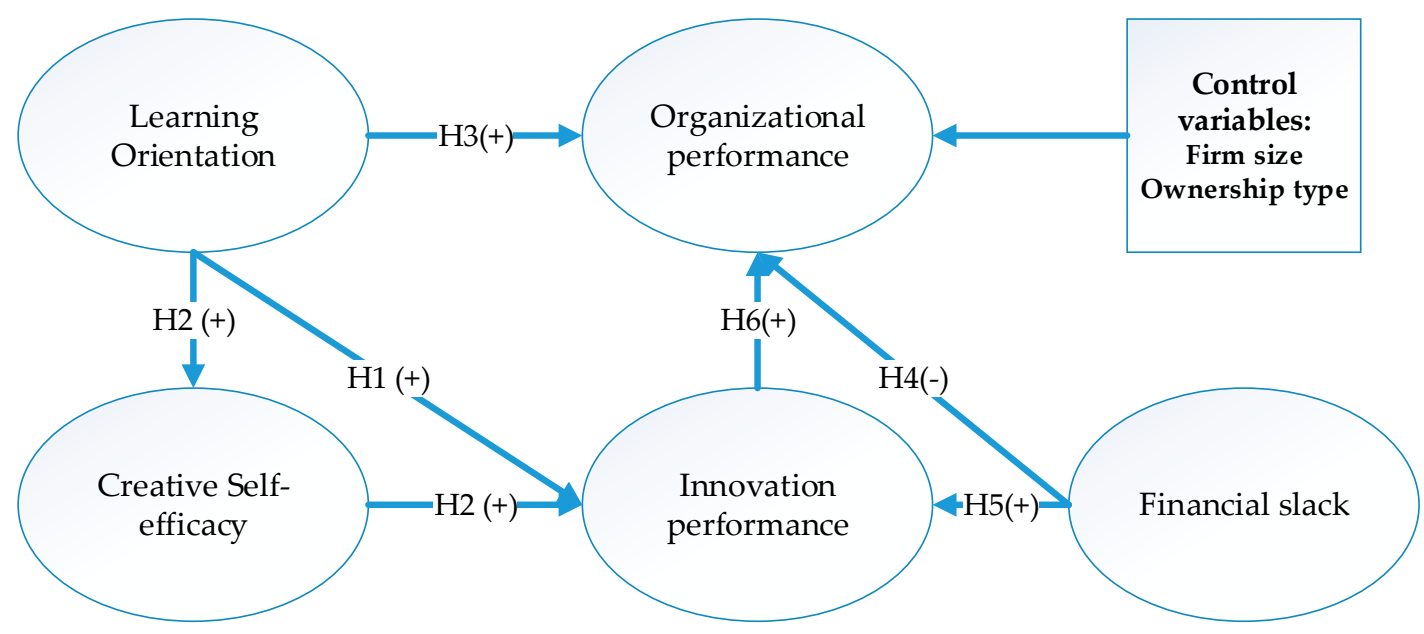

Figure 1. Research framework.

Illustrated the research model with the hypothesis development.

Second, a five-item scale was adapted from (Parida and Örtqvist 2015) to assess innovation performance. Indeed, This was developed by Wang and Ahmed (2004) with 20 items. However, the correspondents in group discussions suggested short scales. As a result, the five-item scales of innovation performance were adapted from (Parida and Örtqvist 2015). They consist of five underlying dimensions: (1) the product; (2) the process; (3) the market; (4) strategy; and (5) behaviour. Product innovation is recognized widely that play a vital role in innovation performance. Pittaway et al. (2004) suggested that developing unique, innovative products or services would help businesses better meet customer needs and achieve and maintain a competitive advantage.

On the other hand, process innovation involves the use of new methods or methods to exploit the organizational resources and capabilities effectively. Market innovation involves the use of a marketing strategy or a new marketing campaign to promote an existing product, as well as introduce a product to a new market or identify a new niche to increase sales. Strategic innovation is referred to the development of new strategies to create value for a company. Finally, behavioural change describes the attitudes of individuals, companies, or managers to novelty. Companies with an innovative behavioural culture can promote new ideas faster and more successfully than those without culture (Wang and Ahmed 2004). Therefore, in order to capture the impact of the proposed possibilities and the financial downturn on the innovation level of small companies, we have adopted a broad perspective on innovation performance.

Third, creative self-efficacy was developed by (Tierney and Farmer 2002). The original sample items were composed of "My past experiences and accomplishments increase my confidence that I will be able to perform successfully in this organization," and "I believe I could have handled a more challenging job than the one I will be doing." (Wang et al. 2014). Then, later studies have adapted and extended more items to measure this construct. We adapted a three-item scale from (Jaiswal and Dhar 2015).

Fourth, financial slack was assessed by a four-item scale following (Boso et al. 2017; Zhang et al. 2018). We asked correspondents to state perceptual comments enclosed: (1) The firm has a satisfactory financial position currently, (2) The firm has easy access to financial capital to support our market operations, (3) The firm has sufficient slack capital and (4) The firm can secure necessary funds if needed.

Finally, a three-item scale was applied by (Fadol et al. 2015) to measure organizational performance. This scale was also used by (Parnell et al. 2012; Jusoh and Parnell 2008) to assess the organizational performance. Specifically, we applied Western measurement scales to the Vietnamese context.

Deciding sample size relies on the statistical estimating precision by a number of variables. Although the greater sample sizes always deliver better projection of the whole population, it is 
proposed that a range from 200 to 400 is considered to be critical for multiple regression and path analysis (Hair et al. 2010). Also, Green (1991) suggest a rule of thumb for determining sample size. Particularly, the sample size $=50+(8 \times$ number of measurement items $)$. Since there were overall 19 items used for the measurement of the model's construct, a total of 202 observations is considered to be the effective sample size.

In addition, many other variables which might influence organizational performance cannot all be included in a single study (Fadol et al. 2015). However, when testing the research hypotheses, the appropriate control variables should be included in the structural equation model. Particularly, with respect to the limited available variables in the data collection, we add two key internal contingencies as two control variables including firm size in terms of employee range and each business type (state-owned enterprise and private owned enterprise) as a dummy variable demoted 0 and 1 , respectively.

\subsection{Data Collection}

The survey questionnaire was designed to enclose questions on the innovative activities of each business and on the subjective perceptions of the entrepreneur regarding the impact of innovation and organizational performance development implementation introduced by the enterprise during the three years previous to the year of the survey (period 2015-2017) and regarding the various dimensions of its current business performance. Data on the characteristics of the enterprise and those of the correspondents and on business strategies were also collected. All types of SMEs were included in the study except self-employed entrepreneurs without employees. The survey was addressed to the person holding the role of the entrepreneur in the firm, defined as "the person who performs principal managerial functions within the business." (Exposito and Sanchis-Llopis 2018). In this regard, several studies have demonstrated empirical evidence that SME managers implement "the most important decisions within their organizations" (Van Gils 2005; Exposito and Sanchis-Llopis 2018), including those regarding innovation strategies and their managerial perceptions shape the firm's strategic behaviour to an essential degree (Alegre et al. 2013; Donate and Pablo 2015). Furthermore, several other studies suppose that self-reported information by managers can be used as an appropriate approach to measure business strategy variables including innovation and business performance (Foreman-Peck 2013; Goya et al. 2016; Madrid-Guijarro et al. 2013; Ramadani et al. 2017; Ribau et al. 2017; Exposito and Sanchis-Llopis 2018; Wang and Ahmed 2004) and financial slacks (Parida and Örtqvist 2015; Boso et al. 2017).

We received valuable support from the Ho Chi Minh City Department of Science and Technology, Vietnam. This organization has organized several seminars to promote and support business start-up and innovation activities in the oriented direction of the social economic development of Ho Chi Minh City. It has recorded the contact information of SMEs which have been participated in seminars. First, it has introduced researchers to contact ten entrepreneurs to conduct in-depth interviews on innovation and development for SMEs. Second, we adopted a snowballing method (Bryman 2012) by asking the first ten entrepreneurs to introduce others who had managed businesses matching the research requirement and then they continued to introduce us with other organization authorities. Third, we also asked for valuable assistance from master students to distribute the survey to their managers who appeared to fit our population of interest. It took six months from January 2018 to June 2018 to contact and distribute 350 questionnaires to SMEs.

We visited each enterprise at least twice to drop off and pick up questionnaires during their working hours. In the first part of the questionnaire, each correspondent provided demographic information, business title, organizational business type and a number of employees. In the second part, the correspondents evaluated key factors in the research framework including learning orientation, creative self-efficacy, innovation performance, financial slack and organizational performance. They filled out the questionnaire survey in Vietnamese version with clear explanation. Some correspondents also called researchers for further explanation when they did not understand some conceptual 
meanings in the questionnaire. All of SMEs in this survey are domestic companies and they have been doing business in both manufacturing and trading industries. We also created a filter question to make sure that each correspondent completely understands the company characteristics such as business strategies, innovation performance, organizational performance and other key constructs in the research model. If they did not have knowledge and experience in any construct of the research requirement, they could stop participating at any time or have the right to refuse to answer any specific question.

Finally, we only received 267 valid observations of organization correspondents from four different business types including 60 state-owned enterprises and 207 private owned enterprises. This also met the effective sample size for conducting path analysis as mentioned above. The correspondents acted on behalf of the organization to answer the questionnaire. The final sample consisted of 160 managers, 38 directors and 69 research and development managers. Among the 267 participants, 135 were female. Among the 267 organizations, $13.48 \%$ had less than 10 employees $(n=36) ; 50.19 \%$ had between 10 and 50 employees $(n=134) ; 22.85 \%$ had between 51 and 100 employees $(n=61)$; and $13.48 \%$ had between 101 and 200 employees $(n=36)$. Table 1 illustrated more details correspondent's demographic characteristics and enterprise's information.

Table 1. Demographic characteristics of correspondents and enterprises.

\begin{tabular}{|c|c|c|}
\hline Characteristics & Number $(N=267)$ & Percentage \\
\hline \multicolumn{3}{|l|}{ Gender } \\
\hline Male & 132 & $50.6 \%$ \\
\hline Female & 135 & $49.4 \%$ \\
\hline \multicolumn{3}{|l|}{ Age } \\
\hline Under 25 & 26 & $9.7 \%$ \\
\hline From 25 to 35 & 131 & $49.1 \%$ \\
\hline From 36 to 45 & 85 & $3.1 .8 \%$ \\
\hline From 46 to 55 & 17 & $6.4 \%$ \\
\hline Over 55 & 8 & $3.0 \%$ \\
\hline \multicolumn{3}{|l|}{ Education level } \\
\hline Bachelor's degree & 203 & $76.0 \%$ \\
\hline Master's degree & 45 & $16.9 \%$ \\
\hline Others & 19 & $7.1 \%$ \\
\hline \multicolumn{3}{|l|}{ Working experience } \\
\hline Under 1 year & 15 & $5.6 \%$ \\
\hline From 1 to 10 years & 155 & $58.1 \%$ \\
\hline From 11 to 20 years & 77 & $28.8 \%$ \\
\hline From 21 to 30 years & 15 & $5.6 \%$ \\
\hline Over 30 years & 5 & $1.9 \%$ \\
\hline \multicolumn{3}{|l|}{ Title in enterprise } \\
\hline Manager & 160 & $59.9 \%$ \\
\hline Director & 38 & $14.3 \%$ \\
\hline Research and Development manager & 69 & $25.8 \%$ \\
\hline \multicolumn{3}{|l|}{ Business type } \\
\hline State-owned enterprises & 60 & $22.5 \%$ \\
\hline Private owned enterprises & 207 & $77.5 \%$ \\
\hline \multicolumn{3}{|l|}{ Number of employees (Firm size) } \\
\hline Less than 10 employees & 36 & $13.5 \%$ \\
\hline From 10 to 50 employees & 134 & $50.2 \%$ \\
\hline From 51 to 100 employees & 61 & $22.8 \%$ \\
\hline From 101 to 200 employees & 36 & $13.5 \%$ \\
\hline
\end{tabular}




\subsection{Data Analysis Technique}

SPSS 22 and AMOS 22 were used for statistical analysis of the data collection. First, exploratory factor analysis (EFA) was conducted to all scales together for a preliminary assessment of dimensionality, convergent and discriminant validity. Second, confirmatory factor analysis (CFA) was implemented to test the full measurement model which included five constructs and their respective items.

\section{Results}

\subsection{Reliability and Construct Validity}

Table 2 showed the self-administrated questionnaire and the descriptive statistics of data collection, including the mean and standard deviation. Specifically, in terms of the reliability, all the Cronbach's alphas of variables were larger than 0.7. Moreover, the testing results showed that the corrected item-total correlations of all items were greater than 0.3 , which satisfy the reliability of the measurement requirement (George and Mallery 2000).

Table 2. Data description and reliability analysis.

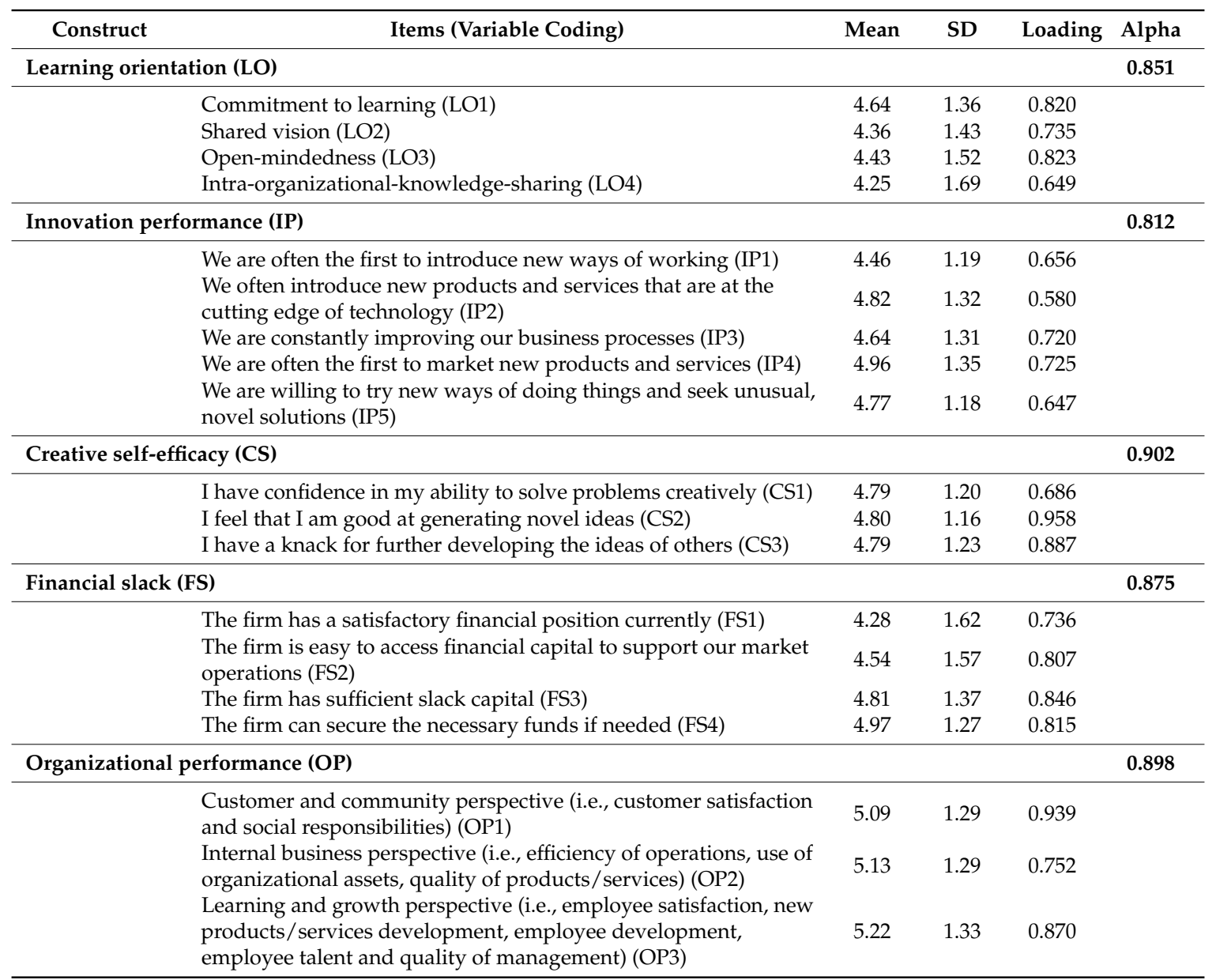

Notes: SD: Standard deviation. 7-point Likert-type scales, with 1 representing strongly disagree to 7 representing strongly agree. Loading items were extracted from Maximum Likelihood with rotation method of Promax.

The exploratory factor analysis was carried out to explore the possible underlying factor and determine whether a set of variables consistently loaded on the same factor based on strong correlations. Particularly, this test is used to "reduce the number of variables as the measurement indicators for the path analysis of overall model" (Lee 2009). According to (Hair et al. 2010), factor loading can be 
classified as practical significance if it is greater than 0.5. Moreover, the Kaiser-Meyer-Olkin (KMO) should be higher than 0.5. Particularly, The KMO measure was 0.852 , which was well within the acceptable limits. The Bartlett's test of Sphericity was fulfilled the significance threshold $(p<0.000)$. The total extracted variance of $62.908 \%(>50 \%)$ indicated that five factors were explained by $62.908 \%$ of the data variability. The factor loadings of valid observed variables were above 0.5 and no major cross-loadings were reported. Then, the study applied Kaiser's eigenvalue with a greater than 1 criterion to identify the five factors that were extracted. In general, the results of the EFA test satisfy these criteria.

Table 2 illustrates the measures of items with their loading results from the exploratory factor analysis. All loading items were higher than 0.5 and Cronbach's alpha coefficients were higher than the threshold (0.6).

Table 3 presented the means and standard deviations as well as the inter-factor correlations matrix for the research variables. Pursuing the two-step approach proposed by (Anderson and Gerbing 1988), we evaluated the measurement criteria before conducting SEM to test the hypotheses. Checking the correlation matrix of seven variables as a preliminary investigation of multicollinearity illustrated that there was no cause for concern since all of the correlation coefficients were less than 0.60 .

Table 3. Means, standard deviation and correlations.

\begin{tabular}{lccccccccc}
\hline Variables & Mean & SD & 1. LO & 2. IP & 3. CS & 4. FS & 5. OP & 6. Type & 7. Size \\
\hline 1. LO & 4.422 & 1.248 & 1.000 & & & & & & \\
2. IP & 4.728 & 0.961 & $0.531^{* * *}$ & 1.000 & & & & & \\
3. CS & 4.794 & 1.096 & $0.545^{* * *}$ & $0.499^{* * *}$ & 1.000 & & & & \\
4. FS & 4.647 & 1.247 & 0.094 & 0.031 & 0.005 & 1.000 & & \\
5. OP & 5.148 & 1.189 & $0.460^{* * *}$ & $0.465^{* * *}$ & $0.510^{* * *}$ & -0.011 & 1.000 & \\
6. Type & 1.78 & 0.418 & 0.062 & 0.115 & 0.090 & -0.055 & 0.060 & 1.000 & \\
7. Size & 2.36 & 0.880 & 0.064 & -0.080 & -0.040 & 0.044 & -0.022 & -0.247 & \multirow{2}{*}{1.000} \\
\hline
\end{tabular}

Notes: ${ }^{* *} p<0.05, * * *<0.01$ (two-tailed). Type: Business ownership (SOE: State-owned enterprise and POE: (Private owned enterprise) is considered as a dummy variable. Size: Enterprise size in terms of employee range.

\subsection{Confirmatory Factor Analysis (CFA)}

The initial measure in analysing the survey data was to evaluate the measurement model through a CFA. The overall fit of the structural model that was initially tested by checking the $Y^{2}$ statistic demonstrated an insufficient fit but this indicator is sensitive to sample size and model complexity (Chen 2008). Hence, we needed to combine other indicators to determine the model fit. According to $\mathrm{Hu}$ and Bentler (1999), the combination rules include $\mathrm{Y}^{2} / \mathrm{df}$ (threshold between 1 and 3), comparative fit index (CFI $>0.90)$, standardized root mean squared residual (SRMS $<0.08)$, root mean squared error of approximation (RMSEA $>0.06$ ) and PClose $>0.05$.

Table 4 reported the CFA test for the overall model (five-factor model). The goodness of fit statistics, which demonstrated a good model fit $(\mathrm{CMIN} / \mathrm{df}=1.529, \mathrm{CFI}=0.976$, SRMS $=0.041$, RMSEA $=0.045$ and PClose $=0.764$ ). Therefore, all of the model fit indices are in accordance with the acceptance requirement. We further undertook a CFA for two constructs including employee learning orientation (LO) and innovation performance (IP). The results indicated a satisfactory fit as presented in Table 4. 
Table 4. Model fit indices in CFA.

\begin{tabular}{cccccc}
\hline $\begin{array}{c}\text { Model Fit } \\
\text { Indices }\end{array}$ & Thresholds & Overall Model & LO & IP & Sources \\
\hline CMIN/DF & $<3$ & 1.529 & 1.174 & 0.115 & (Byrne 2016) \\
CFI & $>0.90$ & 0.976 & 1.000 & 1.000 & (Bentler and Bonett 1980) \\
SRMR & $<0.08$ & 0.041 & 0.004 & 0.007 & (Browne and Cudeck 1993) \\
RMSEA & $<0.06$ & 0.045 & 0.000 & 0.000 & (Byrne 2016) \\
PClose & $>0.05$ & 0.765 & 0.764 & 0.993 & (Byrne 2016) \\
\hline
\end{tabular}

Notes: Chi-square/df (CMIM/DF); Root Mean Squared Error of Approximation (RMSEA); Comparative Fit Index (CFI).

\subsection{Convergent Validity and Discriminant Validity}

To examine the convergent validity of a measurement scale, two indicators were considered: the average variance extracted (AVE) and the composite reliability (CR). The minimum value of the AVE should be at least 0.5 and that of the CR should be greater than the 0.6 cut-off point to ensure the construct convergent validity (Fornell and Larcker 1981). Besides, based on the simulation results of (Fornell and Larcker 1981), a value of AVE between 0.4 and 0.5 may be considered acceptable when the value of the $C R$ is higher than 0.6, in all the measurement models. Furthermore, (Malhotra 2010) also argued that the value of the AVE was too strict and reliability could be established through the CR alone.

After conducting the CFA, the convergent validity met these criteria. Table 5 showed that all estimates and the AVEs of all factors were higher than 0.5 and the composite reliability values of all factors were good (>0.7), except for the AVE of IP, which was equal to 0.465 but its CR was equal to 0.813 . The results fully satisfied the above requirement. In other words, the convergent validities of all constructs were confirmed and the reliability for all constructs and items of this model completely satisfied the criteria.

Table 5. The overall reliability of the construct.

\begin{tabular}{cccccccccc}
\hline Construct & CR & AVE & MSV & ASV & PS & FS & IP & LO & CS \\
\hline Organizational performance (OP) & 0.900 & 0.751 & 0.299 & 0.215 & $\mathbf{0 . 8 6 7}$ & & & & \\
Financial slack (FS) & 0.921 & 0.767 & 0.006 & 0.002 & 0.016 & $\mathbf{0 . 8 7 6}$ & & & \\
Innovation performance (IP) & 0.816 & 0.471 & 0.441 & 0.261 & $0.534^{* * *}$ & -0.001 & $\mathbf{0 . 6 8 6}$ & & \\
Learning orientation (LO) & 0.862 & 0.615 & 0.441 & 0.274 & $0.523^{* * *}$ & 0.076 & $0.664^{* * *}$ & $\mathbf{0 . 7 8 4}$ & \\
Creative self-efficacy (CS) & 0.909 & 0.769 & 0.376 & 0.249 & $0.547^{* * *}$ & -0.004 & $0.565^{* * *}$ & $0.613^{* * *}$ & $\mathbf{0 . 8 7 7}$ \\
\hline
\end{tabular}

Goodness of fit statistics

Chi-square $=209.45 ; \mathrm{df}=137 ; p$ value $=0.000 ; \mathrm{Y}^{2} / \mathrm{df}=1.529 ; \mathrm{CFI}=0.976 ;$ SRMR $=0.041 ;$ RMSEA $=0.045 ;$ PClose $=0.765$

Note: Square root of AVE on diagonal. ${ }^{* * *} p<0.0001$.

We used the correlation between two constructs to measure the discriminant validity. When the $\mathrm{AVE}$ of each measurement item was higher than the square of the biggest correlation estimates of that factor with the maximum shared variance (MSV), the discriminant validity was certified (Fornell and Larcker 1981). Also, the values of the MSV and average shared variance (ASV) were presented with the AVE values. According to (Hair et al. 2010), if all of the ASV and MSV values were lower than their respective AVE values, the discriminant validity conquered. All of these indicators are presented in Table 5. They satisfied the cut-off criteria for determining convergent and discriminant validity.

To examine the issue of frequent method bias, we followed previous studies by implementing Harman's one-factor test (Podsakoff et al. 2003; Mittal and Dhar 2015). The common method bias is a usual problem in a behavioural study where the same correspondents estimate the predictor and criterion variables. To implement this testing procedure, all items were extracted as a principal component factor. The cut-off criterion for the none rotated factor analysis was smaller than 50 per cent. The results illustrated five factors in the research model with the largest "covariance explained by one 
factor" of 35.77 per cent, which was smaller than the threshold value of 50 per cent. We also followed Podsakoff et al. (2003) to check a common latent factor in AMOS. In this approach, all the items were selected to load on their "theoretical constructs and on a latent common factor"; this common factor identified a "common variance among" all the observed variables of the model. The findings demonstrated that the "common variance among" all of the variables was zero. Therefore, the frequent method of bias was not a problem.

Table 6 reported the testing results of SEM in Figure 2. SEM was conducted to estimate the direct and indirect effects. The overall goodness of fit statistics was acceptable and the estimated coefficients were standardized. The finding supported Hypothesis 1 when learning orientation had both a direct effect $(0.498, p<0.001)$ and an indirect impact on innovation performance due to creative self-efficacy $(0.62 \times 0.277=0.172 ; p<0.001$; following the calculation rule of Bollen (1989). Therefore, the total effects of learning orientation on innovation performance were $0.67(p<0.001)$. Furthermore, the findings illustrated that creative self-efficacy positively mediates between learning orientation (the estimate $=0.62, p<0.001$ ) and innovation performance (the estimate $=0.277, p<0.001$ ). Hence, Hypothesis 2 was supported.

Table 6. Structural model results (direct, indirect and total effect).

\begin{tabular}{cccccc}
\hline Effect from & To & H & $\begin{array}{c}\text { Direct } \\
\text { Effects }\end{array}$ & $\begin{array}{c}\text { Indirect } \\
\text { Effects }\end{array}$ & $\begin{array}{c}\text { Total } \\
\text { Effects }\end{array}$ \\
\hline Learning orientation & Innovation performance & H1 & $0.498^{* * *}$ & $0.172^{* * *}$ & $0.670^{* * *}$ \\
Learning orientation & Creative self-efficacy & H2 & $0.620^{* * *}$ & & $0.620^{* * *}$ \\
Creative self-efficacy & Innovation performance & H2 & $0.277^{* * *}$ & $0.277^{* * *}$ \\
Learning orientation & Organizational performance & H3 & $0.310^{* * *}$ & $0.233^{* * *}$ & $0.543^{* * *}$ \\
Innovation performance & Organizational performance & H6 & $0.349^{* * *}$ & & $0.349^{* * *}$ \\
Financial slack & Organizational performance & H4 & -0.061 & -0.005 & -0.066 \\
Financial slack & Innovation performance & H5 & -0.015 & -0.015 \\
\hline The goodness of fit & & CMIN/DF $=2.093$, CFI $=0.937$, SRMR $=0.054$ \\
statistics & & \multicolumn{2}{c}{ RMSEA $=0.064$} \\
\hline
\end{tabular}

Notes: Standardized structural coefficients; ${ }^{* * *} p<0.001$. H: Hypothesis. Two control variables (enterprise size and ownership type) were included in SEM. However, they have no statistically significant impact on organizational performance. Therefore, their estimated coefficients were eliminated.

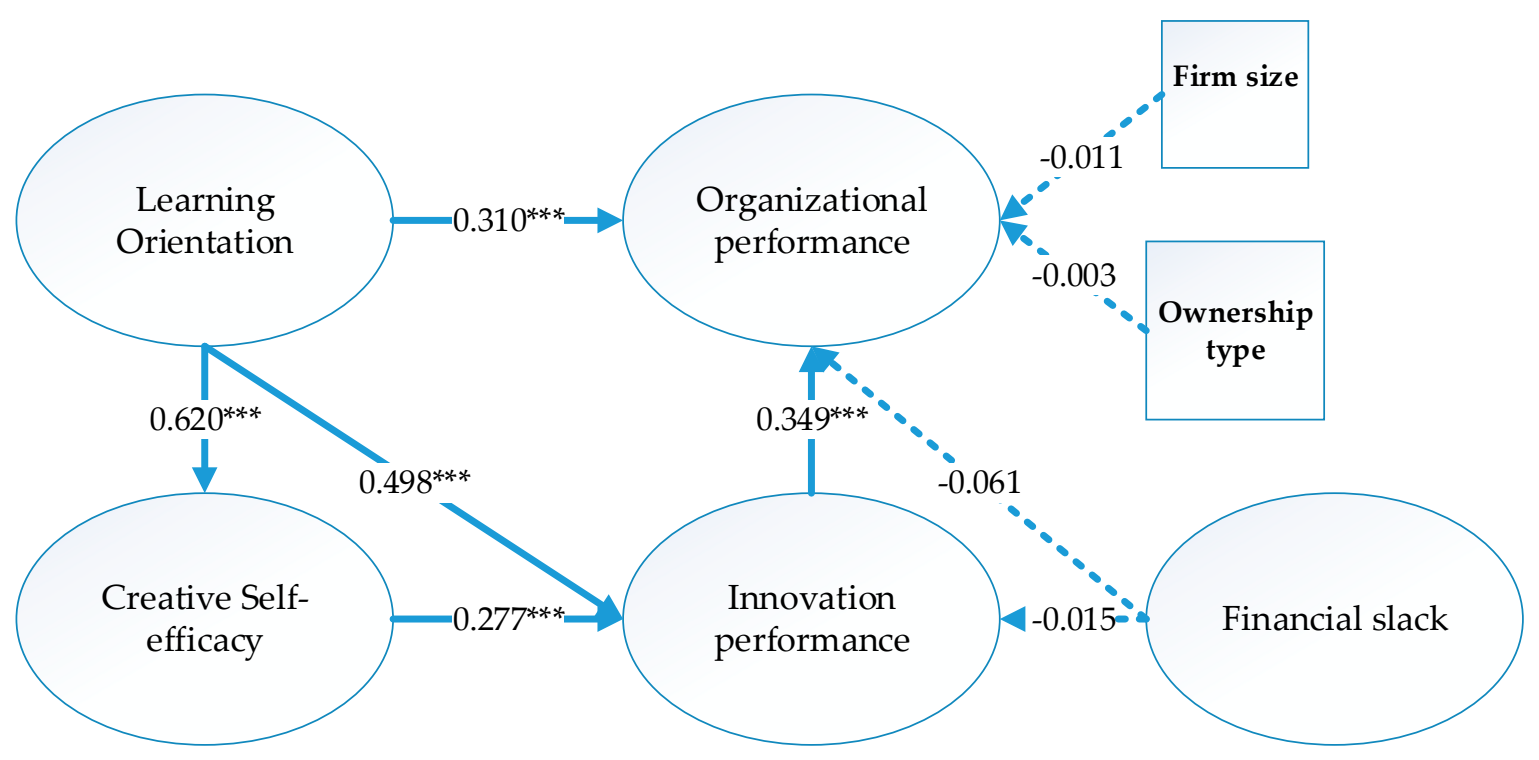

Figure 2. Testing results.

In Table 6, learning orientation was positively associated with organizational performance $(0.310, p<0.001)$. Thus, Hypothesis 3 was supported. Moreover, it also had an indirect effect on 
organizational performance $(0.233, p<0.001)$. This was explained by the AMOS report: when learning orientation increased by one standard deviation, organizational performance increased by 0.233 standard deviations (see (Kline 1998)). In addition, Hypothesis 6 holds because the estimated coefficient verified a positive and statistically significant association between innovation performance and organizational performance $(0.349, p<0.001)$. However, the findings demonstrated no evidence to support Hypotheses 4 and 5.

\section{Discussion and Implications}

These findings are relevant to the intensity and kind of innovation activities and performances for sustainability implementation in SMEs. They have contributed to inspiring research questions. Many previous studies have not explored the causal linkages between creative climate, learning orientation, financial slack, innovation outcomes and organizational performance. Our study attempted to seek answers to such questions by using empirical data to test the direct and indirect influence of innovation performance and creative self-efficacy as mediating variables on the connection between learning orientation and organizational performance. Moreover, this study also examined the direct effect of financial slack on innovation outcomes and organizational performance. Previous studies have rarely investigated these relationships.

One of the fundamental contributions of this study is its confirmation that SMEs have not utilized financial slack to invest in innovation activities and improve firm performance. This result was not consistent with previous theories, which supported that SMEs could utilize financial slack to benefit from pursuing new strategies for innovative solutions such as launching new business models, processes, services and products (Gassmann 2006; Parida and Örtqvist 2015) or developing new markets with potentially high payoffs (Simsek et al. 2007; Voss et al. 2008). In other words, in innovation projects, the determinant logic across the literature is that financial resource slack, instead of constraining actually encourages innovation (Hoegl et al. 2008; Camison-Zornoza et al. 2004). However, the findings provide strong evidence that supports other prior creative studies. These scholars argue that larger financial slack lowers sustainability expense in "developing economy firms due to inherent institutional weaknesses in enforcing compliance with sustainability causes." (Cohen et al. 2008; Cheng et al. 2014; Boso et al. 2017). Indeed, SMEs in Vietnam have been faced with weak capital market, high-interest rates and tough business environment conditions. Thus, they often concentrate on short-term strategies rather than long-term ones for sustainability development. As a result, the effect of financial slack on innovation performance was weakened when SMEs in Vietnam only focused on short-term targets.

In addition, the results also provide evidence to support previous arguments that "the presence of financial slack may itself be inefficient and may signal a lack of entrepreneurial spirit in the organization" (Mishina et al. 2004; Hoegl et al. 2008). Furthermore, firms doing business in developing countries have to create a strong political connection as regulations and laws are poorly enforced in the markets (Peng and Luo 2000; Boso et al. 2017). Therefore, SMEs with slack capital enable to cut their operational expenditures by building business networks with the main government authorities. Similar to a prior finding (Zhao and Lu 2016), our result demonstrated that financial slack had no impact on either innovation performance or organizational performance development in Vietnam.

The empirical results illustrated that the learning organization had a positive impact on employee creative self-efficacy. This finding supports previous arguments that continuous learning will provide plentiful opportunities for employees to explore a variety of perspectives and point of views as well as strengthening a knowledge base to intensify problem-solving skills and innovation process (Amabile 1988; Ericsson et al. 1993; Ford 1996; Gist and Mitchell 1992). This indicates that by consistently improving self-competence, learning-oriented individuals are able to maintain efficacy beliefs via the uncertainty of the creative journey. In other words, the finding also implied that employees with higher levels of creative self-efficacy were more likely to produce more innovative outcomes ((Tierney and Farmer 2004; Tierney and Farmer 2002). Furthermore, according to 
(Yu et al. 2018), social exchange theory forecasts that organizations can encourage individual positive attitudes and behaviours by offering employees inducements. In general, most employees in Vietnamese SMEs are encouraged to pursue lifelong learning by developing competence, accumulating experience and enrolling in higher education. By doing so, they improve their self-competence characteristics.

In line with prior studies, this study illustrated that organizational learning was significant in fostering the ability of SMEs to generate innovation performance by supporting the environment and decision-making that elevates successful organizational performance (García-Morales et al. 2008). Table 6 shows that learning orientation had both a direct and indirect effect on organizational performance. Therefore, the finding supports that organizational learning is more likely to be committed to innovation to meet customer needs and increase competitive advantages (Gatignon and Xuereb 1997).

The increasing significance of employee creative self-efficacy in all types of business organizations has enhanced researchers to seek the mechanisms that foster innovation performance. Previous studies have not fulfilled a consistent gap about what construct mediating impacts of learning orientation and employee creativity on organizational performance through various antecedents. This paper delved into the process of enhancing innovation and sustainable performance through learning orientation and employee creative self-efficacy by considering financial slack. The empirical results support that a good learning environment can promote employee creative self-efficacy, which then gives them the ability to conduct innovation activities and implement sustainable performance. These findings are consistent with prior studies (Tierney and Farmer 2002, 2011; Nieves et al. 2014).

Furthermore, the results also demonstrated that increases in organizational learning and creative self-efficacy were both related to increases in their innovation performance and, in turn, contributed both directly and indirectly to organizational performance. Our results also showed that if employees could be made to feel that they could solve problems creatively as well as to generate novel ideas, then they would engage in innovation initiatives. This result was in line with a recent finding of Camio et al. (2018) that a firm with high creative capabilities would achieve a high innovation performance. It also confirmed the important role of thriving at work in stimulating innovation performance (Riaz et al. 2018).

Our study has several managerial implications for business practitioners. First, SMEs must encourage employees to pursue collaborative learning to accumulate knowledge and experience in promoting creative ideas and conducting innovation projects. A firm has to be innovative and proactive to exist in an unstable business environment. A strong commitment is necessary for managing and disseminating the learning process at all levels of the organization (Wick and León 1995; García-Morales et al. 2008). By doing so, the organization is more likely to implement innovation performance successfully to stimulate sustainability development.

Second, innovation and organizational learning should be provoked to drive performance. This implies that managers should recognize employee creative self-efficacy to support innovation activities in the organization. They should concentrate on generating an environment that is favourable to innovation and learning orientation. They can attempt to share or receive creative ideas. Since innovation does not come from an individual act but is a collaborative achievement, it needs to generate a creative environment that recognizes innovative behaviour, devotes resources to innovation and supposes the culture and structure that cultivates the implementation and development of innovation (García-Morales et al. 2008). Furthermore, managers should also pay more attention to the external environment to meet the stakeholders' needs and requirements and reserve affordable resources for innovation initiatives and organizational performance.

In addition, as SMEs in Vietnam are facing more competition, employees who have creative abilities and a willingness to learn are valuable assets that organizations need to retain and promote. For instance, employees with the ability to generate new products and services can better understand the expectations of customers, while those with the ability to improve business processes can better 
understand the internal business perspective that supports the efficiency of operations and maximizes the use of organizational assets. Most of all, both types of ability are essential for the smooth business operation and profitability of the organization.

\section{Conclusions}

In conclusion, this paper attempted to investigate the role of organizational learning and employee creativity in predicting innovation performance and organizational performance in SMEs in Vietnam. This study provided some evidence in empirical findings that might be generalized to other emerging markets in both business and academic communities, although they may vary in terms of the type of innovation and the performance measures considered. Specifically, it also examined the role of financial slack in stimulating organizational performance and innovation outcomes, although the finding showed that it had no statistically significant effect on both innovation and firm performance. The findings provide directions for leaders to reform organizational policies as well as inspire, motivate and nurture a working environment through such an approach where employees are willing to learn new knowledge, share experience and propose novel ideas to implement innovation projects. In this context, the leaders of SMEs should design training programs and host counselling seminars for their employees so that they are willing to work creatively and contribute to incessant innovation and firm performance. Finally, continuous learning will provide ample opportunities for employees to explore a variety of perspectives and accumulate knowledge to improve their problem-solving skills and initiate innovation processes leading to the achievement of successful organizational performance for sustainable development.

\section{Limitations and Future Research}

Overall, this study still has some limitations. First, our study measures variables based on managerial perceptions of directors (respondents to the application), so the results will affect a certain level of subjectivity. The respondents are directors of enterprises because their knowledge of these strategic variables is significant (e.g., Shortell and Zajac 1990). Second, this study underscores the importance of learning orientation and links it with innovation performance but it does not address the solution for how the learning organization should be implemented. Future research can identify the preconditions of learning orientation and build a comprehensive framework of both the antecedents and consequences. For example, many studies have explored learning from other firms through strategic alliance and other intra-organizational forms (Inkpen 1998). The link between intra-organizational relationships of learning orientation and firm performance can be conducted and further investigated in the future research.

Third, the data collected was cross-sectional, impeding the examination of the evolution of the variables in this study. Because of the dynamic nature of the variable, the results of the study are only considered and considered valid for a certain period. For example, the performance evaluation and performance of an organization's learning orientation should be studied and considered within a specific timeframe. Although authors examine the most likely directions for pathways in the research model, only vertical research can assess the causal orientation of the relationship and detect the possible overlap. The authors attempted to limit this limitation through attention to theoretical arguments by rationalizing the analysed relationships and integrating time considerations into the measurement of variables.

Finally, future studies should analyse a larger sample, preferably in multinational corporations or more countries and in other areas; especially when studying further the impact of financial slack on organizational performance. Although the selected variables explain some of the acceptable variances in organizational performance, the study may analyse other intermediate structures. For example, in the Vietnamese context, evaluating the influences of financial slack on innovation performance on the capacity of the whole organization is influenced by some political constraints or the general situation of the domestic market. Moreover, future research should incorporate the impact of external 
factors on the dynamics of variables (e.g., the influence of the economy on the firm's financial slack), which is also a limitation of this research.

Author Contributions: K.T.T designed the questionnaire, conducted in-depth interviews to complete the survey questionnaire, gave much research advice, and checked the final version. P.V.N developed, wrote the methodology, results, discussions, conclusions and revised all sections. L.M. N wrote the first draft of literature review and revised this section.

Funding: This research received no external funding.

Conflicts of Interest: The authors declare no conflict of interest.

\section{References}

Abernathy, William J., and Kim B. Clark. 1985. Innovation: Mapping the Winds of Creative Destruction. Research Policy 14: 3-22. [CrossRef]

Adams, Mike, and Philip Hardwick. 1998. An Analysis of Corporate Donations: United Kingdom Evidence. Journal of Management Studies 35: 641-54. [CrossRef]

Alegre, Joaquín, and Ricardo Chiva. 2013. Linking Entrepreneurial Orientation and Firm Performance: The Role of Organizational Learning Capability and Innovation Performance. Journal of Small Business Management 51: 491-507. [CrossRef]

Alegre, Joaquín, Kishore Sengupta, and Rafael Lapiedra. 2013. Knowledge Management and Innovation Performance in a High-Tech SMEs Industry. International Small Business Journal 31: 454-70. [CrossRef]

Amabile, Teresa M. 1983. The Social Psychology of Creativity: A Componential Conceptualization. Journal of Personality and Social Psychology 45: 357-76. [CrossRef]

Amabile, Teresa M. 1988. A Model of Creativity and Innovation in Organizations. Research in Organizational Behavior 10: 123-67.

Anderson, James C., and David W. Gerbing. 1988. Structural Equation Modeling in Practice: A Review and Recommended Two-Step Approach. Psychological Bulletin 103: 411-23. [CrossRef]

Ang, Soon, and Detmar W. Straub. 1998. Production and Transaction Economies and IS Outsourcing: A Study of the US Banking Industry. MIS Quarterly 22: 535-52. [CrossRef]

Aragón-Correa, J. Alberto, Nuria Hurtado-Torres, Sanjay Sharma, and Víctor J. García-Morales. 2008. Environmental Strategy and Performance in Small Firms: A Resourcebased Perspective. Journal of Environmental Management 86: 88-103. [CrossRef] [PubMed]

Argyris, Chris, and Donald A. Schon. 1996. Organizational Learning II: Theory, Method, and Practice. London: Addison-Wesley.

Audia, Pino G., and Henrich R. Greve. 2006. Less Likely to Fail: Low Performance, Firm Size, and Factory Expansion in the Shipbuilding Industry. Management Science 52: 83-94. [CrossRef]

Avey, James B., Fred Luthans, and Carolyn M. Youssef. 2010. The Additive Value of Positive Psychological Capital in Predicting Work Attitudes and Behaviors. Journal of Management 36: 430-52. [CrossRef]

Baer, Markus, Greg R. Oldham, Gwendolyn Costa Jacobsohn, and Andrea B. Hollingshead. 2008. The Personality Composition of Teams and Creativity: The Moderating Role of Team Creative Confidence. Journal of Creative Behavior 42: 255-82. [CrossRef]

Baker, William E., and James M. Sinkula. 1999. The Synergistic Effect of Market Orientation and Learning Orientation on Organizational Performance. Journal of Market Focused Management 4: 411-27. [CrossRef]

Bandura, Albert, and Robert Wood. 1989. Effect of Perceived Controllability and Performance Standards on Self-Regulation of Complex Decision-Making. Journal of Personality and Social 56: 805-14. [CrossRef]

Bandura, Albert. 1977. Self-Efficacy: Toward a Unifying Theory of Behavioral Change. Psychological Review 84: 191. [CrossRef] [PubMed]

Bandura, Albert. 1986. Social Foundations of Thought and Action: A Social Cognitive Theory. Englewood Cliffs: Prentice-Hall.

Bandura, Albert. 1991. Self-Regulation of Motivation through Anticipatory and Self-Regulatory Mechanisms. In Perspectives on Motivation: Nebraska Symposium on Motivation 38: 69-164.

Bandura, Albert. 1992. Exercise of Personal Agency through the Self-Efficacy Mechanism. Self-Efficacy: Thought Control of Action 1: 3-37. 
Bandura, Albert. 1997. Self-Efficacy: The Exercise of Control. New York: W.H. Freeman.

Bandura, Albert. 2001. Social Cognitive Theory: An Agentic Perspective. Annual Review of Psychology 52: 1-26. [CrossRef] [PubMed]

Basu, Sudipta, Lee-Seok Hwang, Toshiaki Mitsudome, and Joseph Weintrop. 2007. Corporate Governance, Top Executive Compensation and Firm Performance in Japan. Pacific-Basin Finance Journal 15: 56-79. [CrossRef]

Bentler, Peter M., and Douglas G. Bonett. 1980. Significance Tests and Goodness of Fit in the Analysis of Covariance Structures. Psychological Bulletin 88: 588-606. [CrossRef]

Bhaskaran, Suku. 2006. Incremental Innovations and Business Performance: Small and Medium-Sized Food Enterprises in a Concentrated Industry Environment. Journal of Small Business Management 44: 64-80. [CrossRef]

Biondi, Vittorio, Fabio Iraldo, and Sandra Meredith. 2002. Achieving Sustainability through Environmental Innovation: The Role of SMEs. International Journal of Technology Management 24: 612-26. [CrossRef]

Blum-Kusterer, Martina, and S. Salman Hussain. 2001. Innovation and Corporate Sustainability: An Investigation into the Process of Change in the Pharmaceutical Industry. Business Strategy and the Environment 10: 300-16. [CrossRef]

Bollen, Kenneth A. 1989. Structural Equations with Latent Variables. New York: Wiley-Interscience.

Boons, Frank, and Florian Lüdeke-Freund. 2013. Business Models for Sustainable Innovation: State-of-the-Art and Steps towards a Research Agenda. Journal of Cleaner Production 45: 9-19. [CrossRef]

Boso, Nathaniel, Albert Danso, Constantinos Leonidou, Moshfique Uddin, Ogechi Adeola, and Magnus Hultman. 2017. Does Financial Resource Slack Drive Sustainability Expenditure in Developing Economy Small and Medium-Sized Enterprises? Journal of Business Research 80: 247-56. [CrossRef]

Bourgeois III, L. Jay, and Jitendra V. Singh. 1983. Organizational Slack and Political Behavior among Top Management Teams. Academy of Management Proceedings 1983: 43-47. [CrossRef]

Bourgeois III, L. Jay. 1981. On the Measurement of Organizational Slack. Academy of Management Review 6: 29-39. [CrossRef]

Bradford, Jaryn, and Evan D.G. Fraser. 2008. Local Authorities, Climate Change and Small and Medium Enterprises: Identifying Effective Policy Instruments to Reduce Energy Use and Carbon Emissions. Corporate Social Responsibility and Environmental Management 15: 156-72. [CrossRef]

Bradley, Steven W., Johan Wiklund, and Dean A. Shepherd. 2011. Swinging a Double-Edged Sword: The Effect of Slack on Entrepreneurial Management and Growth. Journal of Business Venturing 26: 537-54. [CrossRef]

Brammer, Stephen, and Andrew Millington. 2004. The Development of Corporate Charitable Contributions in the UK: A Stakeholder Analysis. Journal of Management Studies 41: 1411-34. [CrossRef]

Brislin, R.W., W.J. Lonner, and R.M. Thorndike. 1973. Cross-Cultural Research Methods. New York: John Wiley and Sons.

Bromiley, Philip. 1991. Testing a Causal Model of Corporate Risk Taking and Performance. Academy of Management Journal 34: 37-59.

Brown, Shona L., and Kathleen M. Eisenhardt. 1995. Product Development: Past Research, Present Findings, and Future Directions. Academy of Management Review 20: 343-78. [CrossRef]

Browne, Michael W., and Robert Cudeck. 1993. Alternative Ways of Assessing Model Fit. Sage Focus Editions 154: 136. [CrossRef]

Bryman, Alan. 2012. Social Research Methods, 4th ed. New York: Oxford University Press.

Byrne, Barbara M. 2016. Structural Equation Modeling with AMOS: Basic Concepts, Applications, and Programming, 3rd ed. New York: Routledge.

Cahill, Dennis. 1996. Dialogue. Academy of Management Review 21: 603-5. [CrossRef]

Calantone, J. Roger, S. Tamer Cavusgil, and Yushan Zhao. 2002. Learning Orientation, Firm Innovation Capability, and Firm Performance. Industrial Marketing Management 31: 515-24. [CrossRef]

Camio, Maria Isabel, Maria del Carmen Romero, Maria Belen Alvarez, and Alfredo Jose Rebori. 2018. Distinctive Innovation Capabilities of Argentine Software Companies with High Innovation Results and Impacts. Administrative Sciences 8: 13. [CrossRef]

Camison-Zornoza, Cesar, Rafael Lapiedra-Alcami, Mercedes Segarra-Cipres, and Montserrat Boronat-Navarro. 2004. A Meta-Analysis of Innovation and Organizational Size. Organization Studies 25: 331-61. [CrossRef]

Chen, Ching-Fu. 2008. Investigating Structural Relationships between Service Quality, Perceived Value, Satisfaction, and Behavioral Intentions for Air Passengers: Evidence from Taiwan. Transportation Research Part A: Policy and Practice 42: 709-17. [CrossRef] 
Cheng, Joseph L.C., and Idalene F. Kesner. 1997. Organizational Slack and Response to Environmental Shifts: The Impact of Resource Allocation Patterns. Journal of Management 23: 1-18. [CrossRef]

Cheng, Beiting, Ioannis Ioannou, and George Serafeim. 2014. Corporate Social Responsibility and Access to Finance. Strategic Management Journal 35: 1-23. [CrossRef]

Cohen, Boyd, Brock Smith, and Ron Mitchell. 2008. Toward a Sustainable Conceptualization of Dependent Variables in Entrepreneurship Research. Business Strategy and the Environment 17: 107-19. [CrossRef]

Cooke, Ian, and Paul Mayes. 1996. Introduction to Innovation and Technology Transfer. Norwood: Artech House.

Corso, Mariano, Antonella Martini, Emilio Paolucci, and Luisa Pellegrini. 2001. Information and Communication Technologies in Product Innovation within SMEs-The Role of Product Complexity. Enterprise and Innovation Management Studies 2: 35-48. [CrossRef]

Culbertson, Satoris S., Clive J. Fullagar, and Maura J. Mills. 2010. Feeling Good and Doing Great: The Relationship between Psychological Capital and Well-Being. Journal of Occupational Health Psychology 15: 421-33. [CrossRef] [PubMed]

Cyert, Richard M., and James G. March. 1963. A Behavioral Theory of the Firm. Englewood Cliffs: Prentice-Hall.

Daily, Gretchen C., and Brain H. Walker. 2000. Seeking the Great Transition. Nature 403: 243-45. [CrossRef] [PubMed]

Damanpour, Fariborz. 1991. Organizational Innovation: A Meta Analysis of Effects of Determinants and Moderators. Academy of Management Journal 34: 555-90.

Damanpour, Fariborz. 1987. The Adoption of Technological, Administrative, and Ancillary Innovations: Impact of Organizational Factors. Journal of Management 13: 675-88. [CrossRef]

Dangelico, Rosa Maria, and Devashish Pujari. 2010. Mainstreaming Green Product Innovation: Why and How Companies Integrate Environmental Sustainability. Journal of Business Ethics 95: 471-86. [CrossRef]

Daniel, Francis, Franz T. Lohrke, Charles J. Fornaciari, and R. Andrew Turner Jr. 2004. Slack Resources and Firm Performance: A Meta-Analysis. Journal of Business Research 57: 565-74. [CrossRef]

Danneels, Erwin. 2008. Organizational Antecedents of Second-Order Competences. Strategic Management Journal 29: 519-43. [CrossRef]

DeCarolis, Donna Marie, and David L. Deeds. 1999. The Impact of Stocks and Flows of Organizational Knowledge on Firm Performance: An Empirical Investigation of the Biotechnology Industry. Strategic Management Journal 20: 953-68. [CrossRef]

Deci, Edward, and Richard M. Ryan. 1985. Intrinsic Motivation and Self-Determination in Human Behavior. Plenum Press. New York: Springer Science \& Business Media.

Deephouse, David L., and Robert M. Wiseman. 2000. Comparing Alternative Explanations for Accounting Risk-Return Relations. Journal of Economic Behavior E Organization 42: 463-82.

Delaney, John T., and Mark A. Huselid. 1996. The Impact of Human Resources Management Practices on Perceptions of Organizational Performance. Academy of Management Journal 39: 949-69. [CrossRef]

DiBella, Anthony J., Edwin C. Nevis, and Janet M. Gould. 1996. Understanding Organizational Learning Capability. Journal of Management Studies 33: 361-79. [CrossRef]

Dimick, David E., and Victor V. Murray. 1978. Correlates of Substantive Policy Decisions in Organizations: The Case of Human Resource Management. Academy of Management Journal 21: 611-23.

Dixon, Nancy M. 1992. Organizational Learning: A Review of the Literature with Implications for HRD Professionals. Human Resource Development Quarterly 3: 29-49. [CrossRef]

Dollinger, Marc J. 2008. Entrepreneurship: Strategies and Resources, 4th ed. Hoboken: Marsh Publications.

Donate, Mario J., and Jesús D Sánchez de Pablo. 2015. The Role of Knowledge-Oriented Leadership in Knowledge Management Practices and Innovation. Journal of Business Research 68: 360-70. [CrossRef]

Drake, Frances, Martin Purvis, and Jane Hunt. 2004. Meeting the Environmental Challenge: A Case of Win-Win or Lose-Win? A Study of the UK Baking and Refrigeration Industries. Business Strategy and the Environment 13: 172-86. [CrossRef]

Dweck, Carol S., and Ellen L. Leggett. 1986. Motivational Process Affecting Learning. American Psychologist 41: 1040-48. [CrossRef]

Dweck, Carol S., and Ellen L. Leggett. 1988. A Social-Cognitive Approach to Motivation and Personality. Psychological Review 95: 256-73. [CrossRef]

Dweck, Carol S. 2000. Self-Theories: Their Role in Motivation, Personality, and Development. Philadelphia: Psychological Press. 
Eisenhardt, Kathleen M., and Filipe M. Santos. 2002. Knowledge-Based View: A New Theory of Strategy? Handbook of Strategy and Management 1: 139-64. [CrossRef]

Elbanna, Said. 2012. Slack, Planning, and Organizational Performance: Evidence from the Arab Middle East. European Management Review 9: 99-115. [CrossRef]

Elkington, John. 1997. Cannibals with Forks: The Triple Bottom Line of 21st Century Business, Conscientious Commerce. Oxford: Capstone.

Ericsson, K. Anders, Ralf T. Krampe, and Clemens Tesch-Römer. 1993. The Role of Deliberate Practice in Expert Performance. Psychological Review 100: 363-406. [CrossRef]

Exposito, Alfonso, and Juan A. Sanchis-Llopis. 2018. Innovation and Business Performance for Spanish SMEs: New Evidence from a Multi-Dimensional Approach. International Small Business Journal: Researching Entrepreneurship, 1-21. [CrossRef]

Fadol, Yasir, Belal Barhem, and Said Elbanna. 2015. The Mediating Role of the Extensiveness of Strategic Planning on the Relationship between Slack Resources and Organizational Performance. Management Decision 53: 1023-44. [CrossRef]

Fiol, C. Marlene, and Marjorie A. Lyles. 1985. Organizational Learning. Academy of Management Review 10: 803-13. [CrossRef]

Ford, Cameron M. 1996. A Theory of Individual Creative Action in Multiple Social Domains. Academy of Management Review 21: 1112-42. [CrossRef]

Foreman-Peck, James. 2013. Effectiveness and Efficiency of SME Innovation Policy. Small Business Economics 41: 55-70. [CrossRef]

Fornell, Claes, and David F. Larcker. 1981. Evaluating Structural Equation Models with Unobservable Variables and Measurements Error. Journal of Marketing Research 18: 39-50. [CrossRef]

García-Morales, Víctor J., Francisco Javier Lloréns-Montes, and Antonio J. Verdú-Jover. 2008. The Effects of Transformational Leadership on Organizational Performance through Knowledge and Innovation. British Journal of Management 19: 299-319. [CrossRef]

Gassmann, Oliver. 2006. Opening up the Innovation Pro- Cess: Towards an Agenda. RED Management 36: $223-28$.

Gatignon, Hubert, and Jean-Marc Xuereb. 1997. Strategic Orientation of the Firm and New Firm Performance. Journal of Marketing Research 34: 77-90. [CrossRef]

Geoffrey Love, E., and Nitin Nohria. 2005. Reducing Slack: The Performance Consequences of Downsizing by Large Industrial Firms, 1977-93. Strategic Management Journal 26: 1087-108. [CrossRef]

George, Darren, and Paul Mallery. 2000. SPSS for Windows Step by Step. Boston: Allyn \& Bacon.

George, Gerard. 2005. Slack Resources and the Performance of Privately Held Firms. Academy of Management Journal 48: 661-76. [CrossRef]

Gist, Marilyn E., and Terence R. Mitchell. 1992. Self-Efficacy: A Theoretical Analysis of Its Determinants and Malleability. Academy of Management Review 17: 183-211. [CrossRef]

Goldstein, Susan Meyer, and Albena R. Iossifova. 2012. Ten Years after: Interference of Hospital Slack in Process Performance Benefits of Quality Practices. Journal of Operations Management 30: 44-54. [CrossRef]

Gong, Yaping, Jia Chi Huang, and Jiing Lih Farh. 2009. Employee Learning Orientation, Transformational Leadership, and Employee Creativity: The Mediating Role of Employee Creative Self-Efficacy. Academy of Management Journal 52: 765-78. [CrossRef]

Goya, Esther, Esther Vayá, and Jordi Suriñach. 2016. Innovation Spillovers and Firm Performance: Micro Evidence from Spain (2004-2009). Journal of Productivity Analysis 45: 1-22. [CrossRef]

Grant, Robert M. 1996. Toward a Knowledge-Based Theory of the Firm. Strategic Management Journal 17: 109-22. [CrossRef]

Green, Samuel B. 1991. How Many Subjects Does It Take To Do A Regression Analysis? Multivariate Behavioral Research 26: 499-510. [CrossRef] [PubMed]

Greve, Henrich R. 2003. Organizational Learning from Performance Feedback: A Behavioral Perspective on Innovation and Change. Cambridge: Cambridge University Press.

Hair, Joseph F., William C. Black, Barry J. Babin, Rolph E. Anderson, and R.L. Tatham. 2010. Multivariate Data Analysis, 7th ed. Upper Saddle River: Peason Prentice Hall.

Halme, Minna, and Maria Korpela. 2014. Responsible Innovation toward Sustainable Development in Small and Medium-Sized Enterprises: A Resource Perspective. Business Strategy and the Environment 23: 547-66. [CrossRef] 
Hennessey, Beth A. 2003. Is the Social Psychology of Creativity Really Social? Moving Beyong a Focus on the Individual. In Group Creativity: Innovation Through Collaboration. New York: Oxford University Press, pp. 181-201.

Hillary, Ruth. 2004. Environmental Management Systems and the Smaller Enterprise. Journal of Cleaner Production 12: 561-69. [CrossRef]

Hoegl, Martin, Michael Gibbert, and David Mazursky. 2008. Financial Constraints in Innovation Projects: When Is Less More? Research Policy 37: 1382-91. [CrossRef]

$\mathrm{Hu}$, Li-tze, and Peter M. Bentler. 1999. Cutoff Criteria for Fit Indexes in Covariance Structure Analysis: Conventional Criteria versus New Alternatives. Structural Equation Modeling: A Multidisciplinary Journal 6: 1-55. [CrossRef]

Hult, G. Tomas M., and O.C. Ferrell. 1997. A Global Learning Organization Structure and Market Information Processing. Journal of Business Research 40: 155-66. [CrossRef]

Hult, G. Tomas M. 1998. Managing the International Strategic Sourcing Process as a Market-Driven Organizational Learning System. Decision Sciences 29: 193-216. [CrossRef]

Hurley, Robert F., and G. Tomas M. Hult. 1998. Innovation, Market Orientation, and Organizational Learning: An Integration and Empirical Examination. Journal of Marketing 62: 42-54. [CrossRef]

Inkpen, Andrew C., and Mary M. Crossan. 1995. Believing Is Seeing: Joint Ventures and Organizational Learning. Journal of Management Studies 32: 595-618. [CrossRef]

Inkpen, Andrew C. 1998. Learning and Knowledge Acquisition through International Strategic Alliance. Academy of Management Perspectives 12: 69-80. [CrossRef]

Jaiswal, Neeraj Kumar, and Rajib Lochan Dhar. 2015. Transformational Leadership, Innovation Climate, Creative Self-Efficacy and Employee Creativity: A Multilevel Study. International Journal of Hospitality Management 51: 30-41. [CrossRef]

Jaworski, J Bernard, and Ajay K. Kohli. 1996. Market Orientation: Review, Refinement, and Roadmap. Journal of Market Focused Management 1: 119-35. [CrossRef]

Jensen, Michael C. 1986. Agency Costs of Free Cash Flow, Corporate Finance, and Takeovers. American Economic Review 76: 323-29.

Johannessen, Jon-Arild, Johan Olaisen, and Bjørn Olsen. 1999. Strategic Use of Information Technology for Increased Innovation and Performance. Information Management E Computer Security 7: 5-22.

Julian, Scott D., and Joseph C. Ofori-Dankwa. 2013. Financial Resource Availability and Corporate Social Responsibility Expenditures in a Sub-Saharan Economy: The Institutional Difference Hypothesis. Strategic Management Journal 34: 1314-30. [CrossRef]

Jusoh, Ruzita, and John A. Parnell. 2008. Competitive Strategy and Performance Measurement in the Malaysian Context. Management Decision 46: 5-31. [CrossRef]

Jyoti, Jeevan, and Manisha Dev. 2015. The Impact of Transformational Leadership on Employee Creativity: The Role of Learning Orientation. Journal of Asia Business Studies 9: 78-98. [CrossRef]

Khavul, Susanna, and Garry D. Bruton. 2013. Harnessing Innovation for Change: Sustainability and Poverty in Developing Countries. Journal of Management Studies 50: 285-306. [CrossRef]

Kline, Rex B. 1998. Principles and Practice of Structural Equation Modeling. New York: Guilford Publications.

Kogut, Bruce, and Udo Zander. 1992. Knowledge of the Firm, Combinative Capabilities, and the Replication of Technology. Organization Science 3: 383-97. [CrossRef]

Kornai, Janos. 1979. Resource-Constrained versus Demand-Constrained Systems. Econometrica 47: 801-19. [CrossRef]

Lang, Tseng Ming, Sheng Hsiang Lin, and Truong Nguyen Tuong Vy. 2012. Mediate Effect of Technology Innovation Capabilities Investment Capability and Firm Performance in Vietnam. Procedia Social and Behavioral Sciences 40: 817-29. [CrossRef]

Lant, Theresa K., and David B. Montgomery. 1987. Learning from Strategic Success and Failure. Journal of Business Research 15: 503-17. [CrossRef]

Larson, Andrea L. 2000. Sustainable Innovation through an Entrepreneurship Lens. Business Strategy and the Environment 9: 304-17. [CrossRef]

Leamer, Edward E. 2007. The World Is Flat. Journal of Economic Literature 45: 83-126. [CrossRef]

Lee, Tsung Hung. 2009. A Structural Model to Examine How Destination Image, Attitude, and Motivation Affect the Future Behavior of Tourists. Leisure Sciences 31: 215-36. [CrossRef] 
Leibenstein, Harvey. 1969. Organizational or Frictional Equilibria, X Efficiency, and the Rate of Innovation. Quarterly Journal of Economics 83: 600-23. [CrossRef]

Lin, Han, Saixing Zeng, Haijian Liu, and Chao Li. 2018. Bridging the Gaps or Fecklessness? A Moderated Mediating Examination of Intermediaries' Effects on Corporate Innovation. Technovation. [CrossRef]

Lin, Wen-Ting, Kuei-Yang Cheng, and Yunshi Liu. 2009. Organizational Slack and Firm's Internationalization: A Longitudinal Study of High-Technology Firms. Journal of World Business 44: 397-406. [CrossRef]

Loayza, Norman, Klaus Schmidt-Hebbel, and Luis Servén. 2000. Saving in Developing Countries: An Overview. World Bank Economic Review 14: 393-414. [CrossRef]

Lukas, Bryan A., G. Tomas M. Hult, and O.C. Ferrell. 1996. A Theoretical Perspective of the Antecedents and Consequences of Organizational Learning in Marketing Channels. Journal of Business Research 36: 233-44. [CrossRef]

Luthans, Fred, Bruce J. Avolio, James B. Avey, and Steven M. Norman. 2007. Positive Psychological Capital: Measurement and Relationship with Performance and Satisfaction. Personnel Psychology 60: 541-72. [CrossRef]

Scott, Lyndsey, and Debbie Vigar-Ellis. 2014. Consumer Understanding, Perceptions and Behaviours with Regard to Environmentally Friendly Packaging in a Developing Nation. International Journal of Consumer Studies 38: 642-49. [CrossRef]

Madrid-Guijarro, Antonia, Domingo García-Pérez-de-Lema, and Howard Van Auken. 2013. An Investigation of Spanish Sme Innovation during Different Economic Conditions. Journal of Small Business Management 51: 578-601. [CrossRef]

Majumdar, Sumit K. 1998. Slack in the State-Owned Enterprise: An Evaluation of the Impact of Soft-Budget Constraints. International Journal of Industrial Organization 16: 377-94. [CrossRef]

Malhotra, Naresh K. 2010. Marketing Research: An Applied Orientation. Upper Saddle River: Pearson.

Van Marrewijk, Marcel, and Marco Werre. 2002. Multiple Levels of Corporate Sustainability. Journal of Business Ethics 44: 107-19.

March, James G. 1994. Primer on Decision Making: How Decisions Happen. New York: Simon and Schuster.

McMillan, John, and Christopher Woodruff. 2002. The Central Role of Entrepreneurs in Transition Economies. Journal of Economic Perspectives 16: 153-70. [CrossRef]

Mishina, Yuri, Timothy G. Pollock, and Joseph F. Porac. 2004. Are More Resources Always Better for Growth? Resource Stickiness in Market and Product Expansion. Strategic Management Journal 25: 1179-97. [CrossRef]

Mittal, Swati, and Rajib Lochan Dhar. 2015. Transformational Leadership and Employee Creativity. Journal of Managerial Psychology 30: 645-58. [CrossRef]

Mone, Mark A., William McKinley, and Vincent L. Barker III. 1998. Organizational Decline and Innovation: A Contingency Framework. Acad Manage Rev 23: 115-32. [CrossRef]

Moorman, Christine, and Anne S. Miner. 1998. Organizational Improvisation and Organizational Memory. Academy of Management Review 23: 698-723. [CrossRef]

Morsing, Mette, and Francesco Perrini. 2009. CSR in SMEs: Do SMEs Matter for the CSR Agenda? SSRN 18: 1-6. [CrossRef]

Nguyen, Tho D., and Nigel J. Barrett. 2006. The Adoption of the Internet by Export Firms in Transitional Markets. Asia Pacific Journal of Marketing and Logistics 18: 29-42. [CrossRef]

Nieves, Julia, Agustín Quintana, and Javier Osorio. 2014. Knowledge-Based Resources and Innovation in the Hotel Industry. International Journal of Hospitality Management 38: 65-73. [CrossRef]

Nohria, Nitin, and Ranjay Gulati. 1996. Is Slack Good or Bad for Innovation? The Academy of Management Journal 39: 1245-64. [CrossRef]

Orlitzky, Marc, Frank L. Schmidt, and Sara L. Rynes. 2003. Corporate Social and Financial Performance: A Meta-Analysis. Organization Studies 24: 403-41. [CrossRef]

Ozer, M. 2004. The Role of the Internet in New Product Performance: A Conceptual Investigation. Industrial Marketing Management 33: 355-69. [CrossRef]

Parida, Vinit, and Daniel Örtqvist. 2015. Interactive Effects of Network Capability, ICT Capability, and Financial Slack on Technology-Based Small Firm Innovation Performance. Journal of Small Business Management 53: 278-98. [CrossRef] 
Parnell, John A., Eric B. Dent, Nicholas O’Regan, and Tim Hughes. 2012. Managing Performance in a Volatile Environment: Contrasting Perspectives on Luck and Causality. British Journal of Management 23: S104-18. [CrossRef]

Peng, Mike W., and Yadong Luo. 2000. Managerial Ties and Firm Performance in a Transition Economy: The Nature of a Micro-Macro Link. Academy of Management Journal 43: 486-501. [CrossRef]

Perkins, David N. 1986. Thinking Frames. Educational Leadership 43: 4-10.

Phelan, Sherry, and Angela M. Young. 2003. Understanding Creativity in the Workplace: An Examination of Individual Styles and Training in Relation to Creative Confidence and Creative Self-Leadership. Journal of Creative Behavior 37: 266-81. [CrossRef]

Pitelis, Christos N. 2007. A Behavioral Resource-Based View of the Firm: The Synergy of Cyert and March (1963) and Penrose (1959). Organization Science 18: 478-90. [CrossRef]

Pittaway, Luke, Maxine Robertson, Kamal Munir, David Denyer, and Andy Neely. 2004. Networking and Innovation: A Systematic Review of the Evidence. International Journal of Management Reviews 5: 137-68. [CrossRef]

Podsakoff, Philip M., Scott B. MacKenzie, Jeong-Yeon Lee, and Nathan P. Podsakoff. 2003. Common Method Biases in Behavioral Research: A Critical Review of the Literature and Recommended Remedies. The Journal of Applied Psychology 88: 879. [CrossRef] [PubMed]

Porac, Joseph F., and Howard Thomas. 1990. Taxonomic Mental Models in Competitor Definition. Academy of Management Review 15: 224-40. [CrossRef]

Porter, M.E. 1985. Competitive Advantage: Creating and Sustaining Superior Performance. New York: Free Press.

Ramadani, Veland, Hyrije Abazi-Alili, Léo Paul Dana, Gadaf Rexhepi, and Sadudin Ibraimi. 2017. The Impact of Knowledge Spillovers and Innovation on Firm-Performance: Findings from the Balkans Countries. International Entrepreneurship and Management Journal 13: 299-325. [CrossRef]

Revell, Andrea, and Robert Blackburn. 2007. The Business Case for Sustainability? In the UK's Construction and Restaurant Sectors. Business Strategy and the Environment 16: 404-20. [CrossRef]

Revell, Andrea, David Stokes, and Hsin Chen. 2010. Small Businesses and the Environment: Turning over a New Leaf? Business Strategy and the Environment 19: 273-88. [CrossRef]

Riaz, Sidra, Yusen Xu, and Shahid Hussain. 2018. Understanding Employee Innovative Behavior and Thriving at Work: A Chinese Perspective. Administrative Sciences 8: 46. [CrossRef]

Ribau, Cláudia P., António C. Moreira, and Mário Raposo. 2017. SMEs Innovation Capabilities and Export Performance: An Entrepreneurial Orientation View. Journal of Business Economics and Management 18: 920-34. [CrossRef]

Ritter, Thomas, and Hans Georg Gemünden. 2003. Network Competence: Its Impact on Innovation Success and Its Antecedents. Journal of Business Research 56: 745-55. [CrossRef]

Robinson, Richard N.S., and Lisa G. Beesley. 2010. Linkages between Creativity and Intention to Quit: An Occupational Study of Chefs. Tourism Management 31: 765-76. [CrossRef]

Romanelli, Elaine. 1987. New Venture Strategies in the Microcomputer Industry. California Management Review 30: 160-75. [CrossRef]

Rothaermel, Frank T., and David L. Deeds. 2006. Alliance Type, Alliance Experience and Alliance Management Capability in High Technology Ventures. Journal of Business Venturing 21: 429-60. [CrossRef]

Roy, Marie-Josée, and François Thérin. 2008. Knowledge Acquisition and Environmental Commitment in SMEs. Corporate Social Responsibility and Environmental Management 15: 249-59. [CrossRef]

Rycroft, Robert W., and Don E. Kash. 2000. Steering Complex Innovation. Research Technology Management 43: 13-18. [CrossRef]

Salge, Torsten Oliver, and Antonio Vera. 2013. Smalls Steps That Mmtter: Incremental Learning, Slack Resources and Organizational Performance. British Journal of Management 24: 156-73. [CrossRef]

Salge, Torsten Oliver. 2012. The Temporal Trajectories of Innovative Search: Insights from Public Hospital Services. Research Policy 41: 720-33. [CrossRef]

Sarros, James C., Brian K. Cooper, and Joseph C. Santora. 2008. Building a Climate for Innovation through Transformational Leadership and Organizational Culture. Journal of Leadership E Organizational Studies 15: 145-58.

Seligman, Martin EP, and Mihaly Csikszentmihalyi. 2000. Positive Psychology: An Introduction. Washington: American Psychological Association, vol. 55. 
Senge, Peter M. 2006. The Fifth Discipline: The Art \& Practice of The Learning Organization. New York: Doubleday, Revised \& Updated edition.

Sethi, Rajesh, Daniel C. Smith, and C. Whan Park. 2001. Cross-Functional Product Development Teams, Creativity, and the Innovativeness of New Consumer Products. Journal of Marketing Research 38: 73-85. [CrossRef]

Sharfman, Mark P., Gerrit Wolf, Richard B. Chase, and David A. Tansik. 1988. Antecedents of Organizational Slack. Academy of Management Review 13: 601-14. [CrossRef]

Shin, Shung Jae, and Jing Zhou. 2003. Transformational Leadership, Conservation, and Creativity: Evidence from Korea. Academy of Management Journal 46: 703-14. [CrossRef]

Shortell, Stephen M., and Edward J. Zajac. 1990. Perceptual and Archival Measures of Miles and Snow's Strategic Types: A Comprehensive Assessment of Reliability and Validity. Academy of Management Journal 33: 817-32. [PubMed]

Simsek, Zeki, John F. Veiga, and Michael H. Lubatkin. 2007. The Impact of Managerial Environmental Perceptions on Corporate Entrepreneurship: Towards Understanding Discretionary Slack's Pivotal Role. Journal of Management Studies 44: 1398-424. [CrossRef]

Singh, Jitendra V. 1986. Performance, Slack, and Risk Taking in Organizational Decision Making. Academy of Management Journal 29: 562-85.

Sinkula, James M., William E. Baker, and Thomas Noordewier. 1997. A Framework for Market-Based Organizational Learning: Linking Values, Knowledge, and Behavior. Journal of the Academy of Marketing Science 25: 305-18. [CrossRef]

Sinkula, James M. 1994. Market Information Processing and Organizational Learning. Journal of Marketing 58: 35-45.

Sirmon, David G., Michael A. Hitt, R. Duane Ireland, David G. Sirmon, Michael A. Hitt, and R. Duane Ireland. 2007. Firm Resources in Dynamic Managing To Create Value: Looking Environments Inside the Black Box. Academy of Management Review 32: 273-92. [CrossRef]

Slater, Stanley F., and John C. Narver. 1994. Market Orientation Isn't Enough: Build a Learning Organization. Cambridge: Marketing Science Institute, vol. 94-103.

Sudarmadi, Sigit, Shosuke Suzuki, Tomoyuki Kawada, Herawati Netti, Soeharsono Soemantri, and A. Tri Tugaswati. 2001. A Survey of Perception, Knowledge, Awareness, and Attitude in Regard to Environmental Problems in a Sample of Two Different Social Groups in Jakarta, Indonesia. Environment, Development and Sustainability 3: 169-83. [CrossRef]

Surroca, Jordi, Josep A. Tribo, and Sandra Waddock. 2010. Corporate Responsibility and Financial Performance: The Role of Intangible Resources. Strategic Management Journal 31: 463-90. [CrossRef]

Tan, Justin, and Mike W. Peng. 2003. Organizational Slack and Firm Performance during Economic Transitions: Two Studies from an Emerging Economy. Strategic Management Journal 24: 1249-63. [CrossRef]

Tang, Jintong, K. Michele Micki Kacmar, and Lowell Busenitz. 2012. Entrepreneurial Alertness in the Pursuit of New Opportunities. Journal of Business Venturing 27: 77-94. [CrossRef]

Thompson, James D. 1967. Organization in Action. New York: McGraw-Hill.

Tierney, Pamela, and Steven M. Farmer. 2002. Creative Self-Efficacy: Its Potential Antecedents and Relationship to Creative Performance. Academy of Management Journal 45: 1137-48. [CrossRef]

Tierney, Pamela, and Steven M. Farmer. 2004. The Pygmalion Process and Employee Creativity. Journal of Management 30: 413-32. [CrossRef]

Tierney, Pamela, and Steven M. Farmer. 2011. Creative Self-Efficacy Development and Creative Performance over Time. Journal of Applied Psychology 96: 277-93. [CrossRef] [PubMed]

Uhlaner, Lorraine M., Marta M. Berent-Braun, Ronald J.M. Jeurissen, and Gerrit de Wit. 2012. Beyond Size: Predicting Engagement in Environmental Management Practices of Dutch SMEs. Journal of Business Ethics 109: 411-29. [CrossRef]

Urban, Glen L., and John R. Hauser. 1980. Design and Marketing of New Products. Englewood Cliffs: Prentice-Hall.

Van Gils, Anita. 2005. Management and Governance in Dutch SMEs. European Management Journal 23: 538-89. [CrossRef]

Vanacker, Tom, Veroniek Collewaert, and Ine Paeleman. 2013. The Relationship between Slack Resources and the Performance of Entrepreneurial Firms: The Role of Venture Capital and Angel Investors. Journal of Management Studies 50: 1070-96. [CrossRef] 
Verhees, Frans J.H.M., and Matthew T.G. Meulenberg. 2004. Market Orientation, Innovativeness, Product Innovation, and Performance in Small Firms. Journal of Small Business Management 42: 134-54. [CrossRef]

Verona, Gianmario. 1999. A Resource-Based View of Product Development. Acad Manage Rev 24: $132-42$. [CrossRef]

Von Weizsäcker, Ernst Ulrich, Ernst Ulrich Weizsäcker, Amory B. Lovins, and L. Hunter Lovins. 1998. Factor Four: Doubling Wealth-Halving Resource Use: The New Report to the Club of Rome. London: Earthscan.

Viswanathan, Madhubalan, Srinivas Sridharan, Robin Ritchie, Srinivas Venugopal, and Kiju Jung. 2012. Marketing Interactions in Subsistence Marketplaces: A Bottom-up Approach to Designing Public Policy. Journal of Public Policy \& Marketing 31: 159-77.

Voss, Glenn B., Deepak Sirdeshmukh, and Zannie Giraud Voss. 2008. The Effects of Slack Resources and Environmentalthreat on Product Exploration and Exploitation. Academy of Management Journal 51: 147-64. [CrossRef]

Vu, Xuan Nguyet Hong, and Van Cuong Hoang. 2010. Restructuring Technological Innovation Activities in Vietnam; Hanoi: Ministry of Planning and Investment.

Waddock, Sandra A., and Samuel B. Graves. 1997. The Corporate Social Performance. Strategic Management Journal 8: 303-19. [CrossRef]

Walter, Achim, Michael Auer, and Thomas Ritter. 2006. The Impact of Networking Capabilities and Entrepreneurial Orientation on University Spin-Off Performance. Journal of Business Venturing 21: 541-67. [CrossRef]

Wang, Sophia, and Waiman Cheung. 2004. E-Business Adoption by Travel Agencies: Prime Candidates for Mobile e-Business. International Journal of Electronic Commerce 8: 43-63. [CrossRef]

Wang, Catherine L., and Pervaiz K. Ahmed. 2004. The Development and Validation of the Organisational Innovativeness Construct Using Confirmatory Factor Analysis. European Journal of Innovation Management 7: 303-13. [CrossRef]

Wang, Chung Jen, Huei Ting Tsai, and Ming Tien Tsai. 2014. Linking Transformational Leadership and Employee Creativity in the Hospitality Industry: The Influences of Creative Role Identity, Creative Self-Efficacy, and Job Complexity. Tourism Management 40: 79-89. [CrossRef]

Webster, Leila, and Markus Taussig. 1999. Vietnam's Undersized Engine: A Survey of 95 Larger Private Manufacturers. Hanoi: IFC, Mekong Project Development Facility.

Weisberg, Robert W. 1999. Creativity and Knowledge: A Challenge to Theories. Handbook of Creativity. New York: Cambridge University Press.

Wick, Calhoun W., and Lu Stanton León. 1995. From Ideas to Action: Creating a Learning Organization. Human Resource Management 34: 299-311. [CrossRef]

Wiersma, Eelke. 2017. How and When Do Firms Translate Slack into Better Performance? British Accounting Review 49: 445-59. [CrossRef]

Yu, Ming Chuan, Qiang Mai, Sang Bing Tsai, and Yi Dai. 2018. An Empirical Study on the Organizational Trust, Employee-Organization Relationship and Innovative Behavior from the Integrated Perspective of Social Exchange and Organizational Sustainability. Sustainability 10: 864. [CrossRef]

Zhang, Yixiang, Yimin Wei, and Guanghui Zhou. 2018. Promoting Firms' Energy-Saving Behavior: The Role of Institutional Pressures, Top Management Support and Financial Slack. Energy Policy 115: 230-38. [CrossRef]

Zhao, Hongxin, and Jiangyong Lu. 2016. Contingent Value of Political Capital in Bank Loan Acquisition: Evidence from Founder-Controlled Private Enterprises in China. Journal of Business Venturing 31: 153-74. [CrossRef]

Zinn, Jacqueline, and Ann Barry Flood. 2009. Commentary: Slack Resources in Health Care Organizations-Fat to Be Trimmed or Muscle to Be Exercised? Health Services Research 44: 812-20. [CrossRef] [PubMed]

(C) 2018 by the authors. Licensee MDPI, Basel, Switzerland. This article is an open access article distributed under the terms and conditions of the Creative Commons Attribution (CC BY) license (http:// creativecommons.org/licenses/by/4.0/). 